\title{
Roles of voltage-gated potassium channels in the maintenance of pancreatic cancer stem cells
}

\author{
ATSUSHI SHIOZAKI* ${ }^{*}$ TOMOKI KONISHI ${ }^{*}$, TOSHIYUKI KOSUGA, MICHIHIRO KUDOU, \\ KENTO KURASHIMA, HIROYUKI INOUE, KATSUTOSHI SHODA, TOMOHIRO ARITA, \\ HIROTAKA KONISHI, RYO MORIMURA, SHUHEI KOMATSU, HISASHI IKOMA, ATSUSHI TOMA, \\ TAKESHI KUBOTA, HITOSHI FUJIWARA, KAZUMA OKAMOTO and EIGO OTSUJI \\ Division of Digestive Surgery, Department of Surgery, \\ Kyoto Prefectural University of Medicine, Kyoto 602-8566, Japan
}

Received December 8, 2020; Accepted June 16, 2021

DOI: $10.3892 / \mathrm{ijo} .2021 .5256$

\begin{abstract}
The targeting of membrane proteins that are activated in cancer stem cells (CSCs) represents one of the key recent strategies in cancer therapy. The present study analyzed ion channel expression profiles and functions in pancreatic CSCs (PCSCs). Cells strongly expressing aldehyde dehydrogenase 1 family member A1 (ALDH1A1) were isolated from the human pancreatic PK59 cell line using fluorescence-activated cell sorting, and PCSCs were identified based on tumorsphere formation. Microarray analysis was performed to investigate the gene expression profiles in PCSCs. ALDH1A1 messenger RNA levels were higher in PCSCs compared with non-PCSCs. PCSCs were resistant to 5 -fluorouracil and capable of redifferentiation. The results of the microarray analysis revealed that gene expression related to ion channels, including voltage-gated potassium channels $(\mathrm{Kv})$, was upregulated in PCSCs compared with non-PCSCs. 4-Aminopyridine (4-AP), a potent $\mathrm{Kv}$ inhibitor, exhibited greater cytotoxicity in PCSCs compared with non-PCSCs. In a xenograft model in nude mice, tumor volumes were significantly lower in mice inoculated with PK59 cells pre-treated with 4-AP compared with those in mice injected with non-treated cells. The present results identified a role of $\mathrm{Kv}$ in the persistence of PCSCs and suggested that the Kv inhibitor 4-AP may have potential as a therapeutic agent for pancreatic carcinoma.
\end{abstract}

Correspondence to: Professor Atsushi Shiozaki, Division of Digestive Surgery, Department of Surgery, Kyoto Prefectural University of Medicine, 465 Kajii, Kamigyo, Kyoto 602-8566, Japan E-mail: shiozaki@koto.kpu-m.ac.jp

*Contributed equally

Key words: pancreatic carcinoma, cancer stem cell, voltage-gated potassium channel, 4-aminopyridine, ALDH1A1

\section{Introduction}

Pancreatic cancer is one of the most intractable human malignancies and the seventh leading cause of cancer-related death worldwide (1-3). The 5-year survival rate of pancreatic ductal adenocarcinoma, which is a major histological subtype of pancreatic tumors, remains poor ( $8 \%$ in the USA in 2017, and $15-20 \%$ in Japan in 2018), even after surgery, due to its strongly invasive and metastatic characteristics $(1,4)$. Chemotherapy, including gemcitabine, S-1 and 5-fluorouracil (5-FU), and radiation treatment are the current options for patients with unresectable, recurrent or metastatic cancer (1-4). Although potential drug combinations have been tested in clinical trials, their efficacy is limited due to the drug resistance of pancreatic cancer (5-7). A detailed understanding of the molecular mechanisms regulating the tumorigenesis and progression of pancreatic cancer is needed for the development of more effective treatments.

Accumulating evidence indicates the significance of cancer stem cells (CSCs), which are resistant to current anticancer medicines and radiation, in tumor initiation, progression, recurrence, metastasis and, ultimately, patient death (8-10). Therefore, specific and effective therapies against CSCs are needed, and previous studies have reported the potential of drugs that target CSC markers or signaling pathways (11-15). The targeting of membrane transporters that are specifically upregulated in CSCs represents one of the key novel strategies in cancer treatment.

Membrane transporters and transporters/ion channels have been demonstrated to be involved in the biological processes of cancer cells, and a cellular physiological approach exhibits potential as a potential strategy in specific cancer therapies (16-18). Our previous studies reported that a number of ion channels, including transient receptor potential vanilloid 2 (TRPV2), were highly expressed in squamous cell carcinoma (ESCC) CSCs $(19,20)$. The cytotoxic concentration of tranilast, an analog of a tryptophan metabolite that specifically inhibits TRPV2, needed to suppress cell proliferation was lower for CSCs compared with non-CSCs. Tranilast is typically used in the treatment of inflammatory diseases, such as allergic conjunctivitis, asthma, dermatitis, keloids and hypertrophic 
scars (21). The results of our aforementioned studies suggested that TRPV2 may serve a role in the maintenance and homeostasis of CSCs and may act as a targeted therapeutic agent for ESCC (20). However, transporter/ion channel expression profiles and their oncogenic functions in pancreatic CSCs (PCSCs) have not been examined in detail to date.

Therefore, the aims of the present study were to determine the expression levels and function of transporters/ion channels in PCSCs obtained from pancreatic carcinoma cell lines. The results demonstrated that various genes related to ion channels, including the voltage-gated potassium channel (Kv), were upregulated in PCSCs compared with non-PCSCs. The study also examined whether 4-aminopyridine (4-AP), a Kv inhibitor widely used in the treatment of multiple sclerosis (MS) and Charcot-Marie-Tooth disease, exerted specific inhibitory effects on PCSCs in vitro and in vivo.

\section{Materials and methods}

Cell lines, culture and materials. PK59, PANC1, PK1, PK45H, KP4-1, AsPC1 and SUIT-2 cells were obtained from the Cell Engineering Division in RIKEN BioResource Center and cultured as previously described (20). PK59, PANC1, PK1, PK45H, AsPC1 and SUIT-2 cells were maintained in RPMI-1640 medium (Nacalai Tesque, Inc.) supplemented with $100 \mathrm{U} / \mathrm{ml}$ penicillin, $100 \mu \mathrm{g} / \mathrm{ml}$ streptomycin and 10\% FBS (Nacalai Tesque, Inc.). KP4-1 cells were cultured in DMEM plus HamF12 medium (Nacalai Tesque, Inc.) supplemented with $100 \mathrm{U} / \mathrm{ml}$ penicillin, $100 \mu \mathrm{g} / \mathrm{ml}$ streptomycin and $10 \%$ FBS. Cells were cultured in flasks or dishes in a humidified incubator at $37^{\circ} \mathrm{C}$ with $5 \% \mathrm{CO}_{2}$ in air. 4-AP was purchased from Nacalai Tesque, Inc. 5-FU was purchased from FUJIFILM Wako Pure Chemical Corporation.

Detection of CSCs using Aldefluor fluorescence and cell sorting. The expression of ALDH1A1 in PK59 cells was confirmed using an Aldefluor kit according to the manufacturer's instructions (Stemcell Technologies, Inc.) (20,22). PK59 cells were centrifuged $\left(150 \mathrm{x} \mathrm{g} ; 23^{\circ} \mathrm{C} ; 5 \mathrm{~min}\right)$ and resuspended in Aldefluor Buffer and $3 \mathrm{ml}$ of the resulting cell suspension $\left(1.0 \times 10^{6}\right.$ cells $\left./ \mathrm{ml}\right)$ was mixed with $45 \mu 1$ activated Aldefluor substrate. The mixture with added ALDH1A1 inhibitor diethylaminobenzaldehyde (DEAB) was used as a negative control. Following incubation at $37^{\circ} \mathrm{C}$ for $45 \mathrm{~min}$ away from light, the cells were centrifuged $\left(150 \mathrm{x} \mathrm{g} ; 23^{\circ} \mathrm{C} ; 5 \mathrm{~min}\right)$, resuspended $\left(1.0 \times 10^{6}\right.$ cells $\left./ \mathrm{ml}\right)$ in Aldefluor Buffer and maintained on ice for $1 \mathrm{~h}$. The cells were subsequently isolated by flow cytometry using the Cell Sorter SH800 (Sony Corporation) and categorized into two subgroups based on fluorescence and cell scattering. Cells expressing ALDH1A1 treated with or without 4-AP were analyzed using the BD Accuri C6 flow cytometer and the associated software (BD Biosciences).

CSC culture. Cells expressing high levels of ALDH1A1 were separated from PK59 cells using FACS and cultured in tumorsphere medium containing RPMI-1640 medium with $100 \mathrm{U} / \mathrm{ml}$ penicillin, $100 \mu \mathrm{g} / \mathrm{ml}$ streptomycin, 2\% B27 supplement (Gibco; Thermo Fisher Scientific, Inc.), $10 \mathrm{ng} / \mathrm{ml}$ epidermal growth factor and $10 \mathrm{ng} / \mathrm{ml}$ fibroblast growth factor (both Invitrogen; Thermo Fisher Scientific, Inc.) for 7 days in ultra-low attachment 6-well plates (Corning, Inc.) (20). The presence of tumorspheres in plates was detected under an inverted light microscope (magnification, $\mathrm{x} 40)$. Tumorspheres were recovered by centrifugation (300 x g; $\left.23^{\circ} \mathrm{C} ; 10 \mathrm{~min}\right)$, counted, and dissociated into single cells by processing with trypsin-EDTA and gentle mechanical crushing using a glass pipette (20). The obtained single cells were re-plated to allow the reformation of spheres. The spheres were passaged every 4-7 days when their diameter reached $\sim 100 \mu \mathrm{m}(20)$.

Drug sensitivity test. PCSCs separated from adherent and spheroid PK59 cells were seeded in 96-well microplates at a concentration of 2,000 cells/well. The cells were treated with increasing concentrations of 5-FU or 4-AP for $72 \mathrm{~h}(5-\mathrm{FU}$, 0.16-80 $\mu \mathrm{M}$; 4-AP, 0.08-40 mM). WST-8 assay (Cell Count Reagent SF; Nacalai Tesque, Inc.) was performed to evaluate the viability of cells treated with 5-FU or 4-AP. A total of $10 \mu \mathrm{l}$ of this reagent was added per well and the cells were incubated for $90 \mathrm{~min}$ at $23^{\circ} \mathrm{C}$. The number of viable cells was determined by measuring absorbance at $490 \mathrm{~nm}$ using microplate reader.

Reverse transcription-quantitative (RT-qPCR). Total RNA was extracted from PK59 cells and PK59 CSCs using an RNeasy kit (Qiagen, Inc.); the concentration of the cells before RNA extraction was not measured. The concentration of RNA was measured after extraction, and the RNA concentration was adjusted to $50 \mathrm{ng} / \mu \mathrm{l}$. Reverse transcription was performed using a High-Capacity cDNA Reverse Transcription kit (Applied Biosystems; Thermo Fisher Scientific, Inc.) as follows: $25^{\circ} \mathrm{C}$ for $10 \mathrm{~min}, 37^{\circ} \mathrm{C}$ for $120 \mathrm{~min}$ and $85^{\circ} \mathrm{C}$ for $5 \mathrm{~min}$ ). The 7300 Real-Time PCR System (Applied Biosystems; Thermo Fisher Scientific, Inc.) with TaqMan Gene Expression Assays (Applied Biosystems; Thermo Fisher Scientific, Inc.) were used according to the manufacturer's instructions. The PCR thermocycling conditions were as follows: Initial denaturation at $95^{\circ} \mathrm{C}$ for $10 \mathrm{~min}$, followed by 40 cycles of $95^{\circ} \mathrm{C}$ for $15 \mathrm{sec}$ and at $60^{\circ} \mathrm{C}$ for $1 \mathrm{~min}$. The expression levels of the following mRNAs were determined: ALDH1A1 (cat. no. HS00946916_m1), potassium voltage-gated channel $(\mathrm{KCN})$ subfamily $\mathrm{B}$ member 1 (KCNB1; cat. no. Hg00270657_m1), KCNC1 (cat. no. $\left.\mathrm{Hg} 00428197 \_m 1\right), \mathrm{KCND} 1$ (cat. no. Hg01085825_m1), SOX2 (cat. no. Hs01053049_s1), CD44 (cat. no. Hs00153304_m1), CD133 (cat. no. Hs01009259_m1), and CXCR4 (cat. no. Hs00607978) (all Applied Biosystems; Thermo Fisher Scientific, Inc.). The expression levels were normalized to those of the housekeeping gene $\beta$-actin (cat.no. Hs01060665_g1; Applied Biosystems; Thermo Fisher Scientific, Inc.). Assays were performed in triplicate.

Small interfering RNA (siRNA) transfection. PK59 cells were seeded at a density of $1.0 \times 10^{5}$ cells/well on 6 -well plates and were transfected with $20 \mathrm{nM}$ ALDH1A1 or KCNB1 siRNA (Stealth RNAi ${ }^{\mathrm{TM}}$; cat. nos. HSS100366 and HSS180043; Invitrogen; Thermo Fisher Scientific, Inc.) using the Lipofectamine ${ }^{\circledR}$ RNAiMAX reagent (Invitrogen; Thermo Fisher Scientific, Inc.) according to the manufacturer's instructions. The cells were incubated with the transfection mixture at 
$37^{\circ} \mathrm{C}$ for $24 \mathrm{~h}$, following which the medium was replaced. The Stealth RNAi ${ }^{\mathrm{TM}}$ siRNA negative control (cat. no. 12935112; Invitrogen; Thermo Fisher Scientific, Inc.) was used as the negative control. The siRNA sequences were as follows: ALDH1A1 siRNA sense, 5'-CAGGAACAGUGUGGGUGA AUUGCUA-3' and antisense, 5'-UAGCAAUUCACCCAC ACUGUUCCUG-3'; and KCNB1 siRNA sense, 5'-CCUAAG UUCUUAAGGCAGAACUGUA-3' and antisense, 5'-UAC AGUUCUGCCUUAAGAACUUAGG-3'.

Assessment of overexpression. Unsorted PK59 cells were transfected with the control HaloTag plasmid (cat. no. G6591), ALDH1A1 HaloTag plasmid (cat. no. FHC09770) or KCNB1 HaloTag plasmid (cat. no. FXC27060) using FuGENE HD transfection reagents (cat. no. E2311) (all Promega Corporation) according to the manufacturer's instructions. Vector transfection was confirmed by fluorescence microscopy to detect the HaloTag fusion protein stained by the tetramethylrhodamine-conjugated HaloTag ligand (cat.no. G8252; Promega Corporation) according to the manufacturer's protocol. A cell proliferation assay was subsequently conducted using ALDH1A1-expressing cells. Briefly, PK59 cells were seeded in 6-well plates at a density of $0.75 \times 10^{5}$ cells/well and incubated at $37^{\circ} \mathrm{C}$ with $5 \% \mathrm{CO}_{2}$ for $24 \mathrm{~h}$. Subsequently, the cells were transfected with plasmid as aforementioned, detached from the flasks with trypsin-EDTA at 48 and $72 \mathrm{~h}$ post-transfection and counted with a hemocytometer.

Cell counting. Unsorted PK59 cells were seeded in 6-well plates at a density of $0.75 \times 10^{5}$ cells/well and incubated at $37^{\circ} \mathrm{C}$ with $5 \% \mathrm{CO}_{2}$ for $24 \mathrm{~h}$. Subsequently, the cells were transfected with siRNA as aforementioned, detached from the flasks with trypsin-EDTA at $72 \mathrm{~h}$ post-transfection and counted with a hemocytometer.

Sample preparation and hybridization to microarrays. Total RNA (50 ng/ $\mu \mathrm{l}$ ) was extracted from PK59 cells and PK59 CSCs using an RNeasy kit (Qiagen, Inc.), aforementioned. Microarray analyses were performed by Takara Bio, Inc. using the Agilent SurePrint G3 Human Gene Expression 8x60 K microarray (Agilent Technologies, Inc.). RNA quality was assessed using an Agilent 2100 Bioanalyzer (Agilent Technologies, Inc.). Total RNA was labeled with Cyanine-3 (Cy3) using a Low Input Quick Amp Labeling kit (Agilent Technologies, Inc.). Samples were purified on RNeasy columns (Qiagen, Inc.). The Cy3-labeled cRNA was fragmented and subsequently hybridized for $17 \mathrm{~h}$. Following hybridization, the slides were washed and immediately scanned with an Agilent DNA Microarray Scanner (cat. no. G2565CA; Agilent Technologies, Inc.) using the one-color setting for $8 \times 60 \mathrm{~K}$ array slides.

Microarray data processing. Scanned images of the microarray slides were examined using Feature Extraction Software 10.10 (Agilent Technologies, Inc.) with default parameters to obtain signal intensities with background subtraction and spatial detrending. Gene expression profiles and functions were assessed with Ingenuity Pathway Analysis (IPA) software (Ingenuity Systems, Inc.) as previously described $(17,19,20)$. The obtained datasets have been submitted to the public curated database Gene Expression Omnibus (GSE172185) (https://www.ncbi.nlm.nih.gov/geo).
Formation of tumorspheres. PCSCs were suspended in medium with or without $5 \mathrm{mM}$ of 4 -AP, seeded at 100 or 200 cells/well in 96 -well plates and incubated at $37^{\circ} \mathrm{C}$ with $5 \% \mathrm{CO}_{2}$ in air for one week. To exclude any potential disturbances to the formation of tumorspheres, no changes were made to the culture medium. The formed spheres were counted using a phase-contrast microscope under $\mathrm{x} 40$ magnification as previously described $(20,23)$.

Measurement of the intracellular concentration of chloride $\left[\left(\mathrm{Cl}^{-}\right)\right]_{i} \cdot\left[\mathrm{Cl}^{-}\right]_{\mathrm{i}}$ was assessed using the MQAE reagent (Dojindo Laboratories, Inc.), a chloride-sensitive fluorescent probe (24). PK59 cells were seeded in 24-well plates at a density of $4 \times 10^{4}$ cells/well and incubated at $37^{\circ} \mathrm{C}$ with $5 \% \mathrm{CO}_{2}$ for $48 \mathrm{~h}$. Subsequently, MQAE reagent dissolved in complete RPMI-1640 medium was applied, and the plates were incubated at $37^{\circ} \mathrm{C}$ in a $\mathrm{CO}_{2}$ incubator for $12 \mathrm{~h}$. The plates were washed five times with PBS, and the fluorescence intensity of MQAE was measured by fluorescence microscopy (BZ-X810; Keyence Corporation); three fields of view were analyzed per sample at x100 magnification. Quantification was performed using a BZ-X810 analyzer and accompanying software (v.1.1.1.8; Keyence Corporation).

Animal experimental protocol. All animal protocols were approved by the by the Institutional Review Board of the Kyoto Prefectural University of Medicine (Kyoto, Japan; approval no. M2019-267), and all experiments were strictly conducted in accordance with the National Institute of Health Guide for the Care and Use of Laboratory Animals. A total of 27 female BALB/c nude mice (age, 4 weeks) were obtained from Shimizu Laboratory Supplies Co., Ltd. and maintained under pathogen-free barrier conditions. The mice were provided with ad libitum access to sterile food and water and housed with a 12 -h light-dark cycle at $24^{\circ} \mathrm{C}$ and $40-70 \%$ humidity. Suspensions of $5 \times 10^{5}$ PK59 cells in $50 \mu 1$ RPMI-1640 and $50 \mu 1$ Matrigel matrix (Corning, Inc.) incubated with $5 \mathrm{mM}$ 4-AP for $48 \mathrm{~h}$ in vitro were subcutaneously injected into the right side of the lower flanks of 4-week-old female nude mice, and suspensions containing the same number of PK59 cells incubated without 4 -AP were injected into the left side $(n=3)$. To investigate the influence that the expression of ALDH1A1 has on tumor growth, suspensions of $5 \times 10^{5}$ PK59 cells transfected with control siRNA, ALDH1A1 siRNA, control plasmid or ALDH1A1 plasmid in vitro were injected subcutaneously into the lower flanks of 4 -week-old female nude mice $(n=3$ mice/group). For the assessment of drug combination treatment, suspensions of $5 \times 10^{5}$ PK59 cells incubated with 4-AP, 5 -FU or 5-FU combined with 4 -AP for $48 \mathrm{~h}$ in vitro were injected subcutaneously into the lower flanks of 4-week-old female nude mice ( $\mathrm{n}=3$ mice). All 27 mice were sacrificed using pentobarbital $(120 \mathrm{mg} / \mathrm{kg}) 28$ days or 35 days after the injection, and the volumes of resected tumors were measured. The volumes of tumors were calculated according to the following formula (25): Tumor volume $\left(\mathrm{mm}^{3}\right)=1 / 2 \mathrm{x}$ length $\mathrm{x}$ width ${ }^{2}$.

Humane endpoints were reached when the xenograft tumor reached $>10 \%$ of the animal body weight, the tumor diameter was $>20 \mathrm{~mm}$, tumors metastasized or grew such that it led to rapid body weight loss $(>20 \%)$, or signs of immobility, a huddled posture, the inability to eat, ruffled 
fur, self-mutilation, ulceration, infection or necrosis were observed. All 27 animals reached the study endpoints (on day 28 or 35) and were euthanized by cervical dislocation under anesthesia by intraperitoneal injection of pentobarbital $(70 \mathrm{mg} / \mathrm{kg}$ ). Death was verified by the cessation of a heartbeat and dilated pupils.

Immunohistochemistry. Xenograft samples were embedded in paraffin following $12-\mathrm{h}$ formalin fixation at $4^{\circ} \mathrm{C}$. Immunohistochemistry for the ALDH1A1 protein was performed on $4-\mu$ m-thick paraffin sections of tumor tissues using the avidin-biotin-peroxidase method. After dewaxing paraffin sections with xylene and hydration in a graded ethanol series $(99.5,90,70$ and 50\%), endogenous peroxidases were blocked by an incubation in $0.3 \% \mathrm{H}_{2} \mathrm{O}_{2}$ for $30 \mathrm{~min}$ at $23^{\circ} \mathrm{C}$. An Avidin/Biotin Blocking kit (Vector Laboratories, Inc.) was used to block endogenous biotin, biotin receptors and avidin-binding sites. The sections were subsequently treated with a protein blocker and incubated at $4^{\circ} \mathrm{C}$ overnight with an anti-ALDH1A1 antibody (1:300; cat. no. 611194; BD Pharmingen; BD Biosciences), followed by visualization of the avidin-biotin-peroxidase complex using the Vectastain ABC Elite kit (Vector Laboratories, Inc.) with diaminobenzidine tetrahydrochloride. The sections were counterstained with hematoxylin for $4 \mathrm{~min}$ at $23^{\circ} \mathrm{C}$ and subjected to dehydration in a graded ethanol series (50, 70, 90 and 99.5\%), cleared in xylene and mounted in Entellan new (Sigma-Aldrich, Inc.). Quantification of staining intensity was performed using BZ-X800 All-in-one fluorescence microscope and analyzer software (magnification, $\mathrm{x} 400 ; \mathrm{n}=3 \mathrm{mice} / \mathrm{group}$ ).

Correlation analysis in databases. Correlation analysis was performed using cBioportal (www.cbioportal.org). Using the human genome assembly hg19/GRCh37, the gene expression at the mRNA level of each case in databases was investigated. After selection of the database, TCGA, PanCancer Atlas, the gene name 'ALDH1A1' was entered and referred to the co-expression. This co-expression function enables the investigation the relationships of gene expression between ALDH1A1 and other genes. Spearman correlation between the expression levels of ALDH1A1 and Kv in primary tumor samples of human pancreatic cancer was performed using cBioPortal.

Statistical analysis. All statistical analyses were conducted using the statistical software JMP (version 12; SAS Institute, Inc.). Statistical analysis was performed using the Mann-Whitney U test for two-group comparisons. One-way ANOVA was used to compare the differences among multiple groups, followed by Tukey's multiple comparisons post-hoc test. In the drug sensitivity assay, $\mathrm{IC}_{50}$ values were calculated based on a non-linear regression. Data are presented in the graphs as the mean \pm SEM. $\mathrm{P}<0.05$ was considered to indicate a statistically significant difference.

\section{Results}

Acquisition of CSCs. The Aldefluor assay was performed using PK59 cells to isolate cells that expressed high levels of ALDH1A1 by FACS (Fig. 1A). The proportion of CSCs in the PK59 cell line was $3.9 \%$. To confirm the characteristics of CSCs, tumorsphere formation assay was performed, and the formation of tumorspheres was observed under a microscope (Fig. 1B). Total RNA was extracted from tumorspheres, and RT-qPCR was used to compare ALDH1A1 mRNA levels in adherent PK59 cells (non-CSCs) and spheres (CSCs). Among PK59 cells, CSCs exhibited higher ALDH1A1 mRNA levels compared with those in non-CSCs (Fig. 1C). The Aldefluor assay was also performed using other pancreatic cell lines, including PANC1, PK1, PK45H, KP4-1, AsPC1 and SUIT-2 (Fig. S1). Cells that strongly expressed ALDH1A1 were only isolated from three cell lines, namely PANK1, PK4-1 and SUIT-2 (Fig. S1B). Among them, only cells isolated from SUIT-2 proliferated. However, SUIT-2 cells expressing high levels of ALDH1A1 did not form fine spheres in the sphere formation assay (Fig. S1C). Thus, only CSCs from the PK59 cell line were examined in the present study.

To clarify whether established CSCs were capable of redifferentiation, CSCs were seeded on normal plates in culture medium. Three days later, these cells were observed to possess adhesive properties and typical morphologies (Fig. 1D). The CSCs and non-CSCs of PK59 cells were treated with 5-FU to determine their resistance to anticancer drugs. The $\mathrm{IC}_{50}$ values were $\sim 3.47$ and $6.07 \mu \mathrm{M}$ in non-CSCs and CSCs, respectively (Fig. 1E). These results suggested that the cytotoxicity of 5-FU was greater at lower concentrations in non-CSCs compared with that in CSCs, which reflected the properties of CSCs. The properties of CSCs were further assessed using comparative analyses between sorted PK59 cells and unsorted PK59 cells of the expression profiles of other previously reported PCSC markers, such as CD44, CD133 and SOX2 $(4,26,27)$. In addition, ALDH1A1 overexpression and knockdown experiments were performed to investigate its effects on cell proliferation. ALDH1A1 mRNA levels were significantly increased by the overexpression of ALDH1A1 in PK59 cells compared with those in the control group (Fig. 2A), and CD44 and CD133 mRNA levels were also significantly elevated (Fig. 2B). The number of ALDH1A1 plasmid-transfected PK59 cells at $72 \mathrm{~h}$ post-transfection was significantly higher compared with that of the control cells (Fig. 2C). ALDH1A1 and SOX2 mRNA levels were markedly decreased by the transfection of ALDH1A1 siRNA into PK59 cells (Fig. 3A and B). Tumorigenicity following transfection was slightly weaker in nude mice inoculated with ALDH1A1 siRNA-transfected PK59 cells compared with those injected with the control cells (Fig. 3C). By contrast, tumorigenicity was slightly stronger in nude mice inoculated with ALDH1A1 plasmid-transfected PK59 cells compared with that in mice injected with control cells (Fig. 3D). These results suggested a potential relationship between ALDH1A1 and tumor formation, although not statistically significant in the three mice, which supported the rationale for PK59 cells strongly expressing ALDH1A1 to be defined as PCSCs.

Gene expression in PK59 CSCs. Gene expression data from PK59 CSCs and non-CSCs were obtained using microarray and bioinformatics analyses. The results of the microarray analysis revealed that the expression levels of 4,870 genes in PK59 CSCs exhibited fold-changes $>3.0$ compared with those in non-CSCs. Among these, the expression levels of 2,739 genes were upregulated, whereas the levels of 2,131 genes were downregulated in PK59 CSCs. A list of 50 genes with the greatest increases and decreases in expression levels in PK59 CSCs is presented 
A

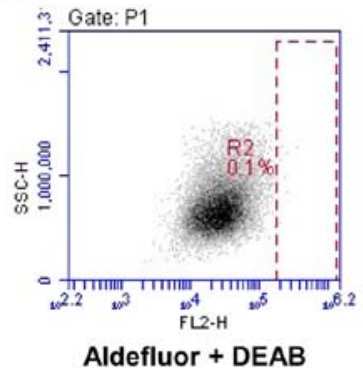

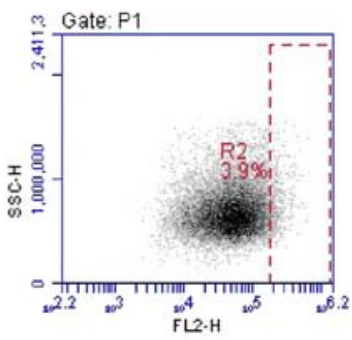

Aldefluor
B

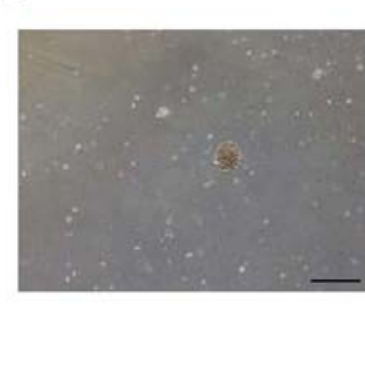

C

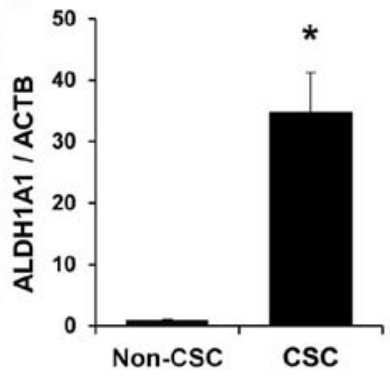

D

CSC-PK59

Re-differentiated CSC-PK59

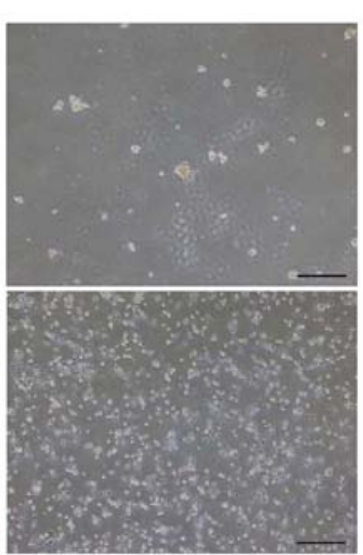

E

Non-CSC

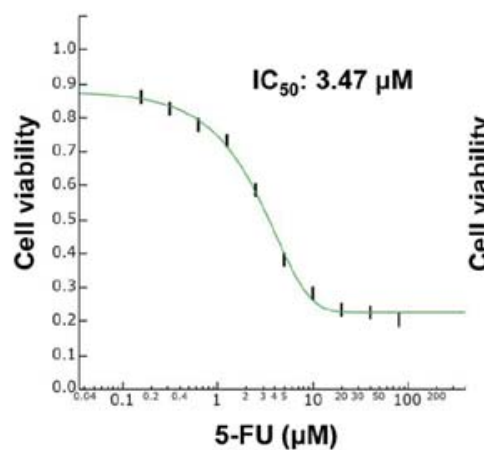

csc

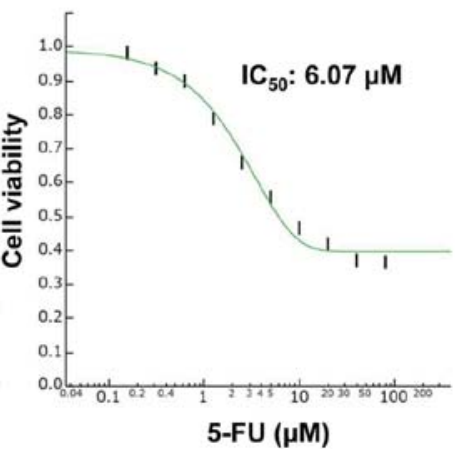

Figure 1. Acquisition of CSCs in PK59 cells. (A) Aldefluor assay in PK59 cells. Cells strongly expressing ALDH1A1 were isolated using FACS. A specific inhibitor of ALDH, DEAB, was used to control for background fluorescence. (B) Sorted PK59 cells strongly expressing ALDH1A1 formed spheres in the sphere formation assay. Magnification, x40. Scale bar, $500 \mu \mathrm{m}$. (C) ALDH1A1 mRNA expression levels were increased in CSCs compared with those in non-CSC. Data are presented as the mean \pm SEM. $n=3$. ${ }^{*} \mathrm{P}<0.05$ vs. non-CSCs. (D) The obtained CSCs exhibited the ability to redifferentiate. CSCs cultured on normal plates acquired adhesive properties and a typical morphology. Magnification, $\mathrm{x} 40$. Scale bar, $500 \mu \mathrm{m}$. (E) Anticancer drug sensitivity of CSCs. 5-FU was more cytotoxic at a lower concentration in non-CSCs compared with in CSCs in PK59 cells. $\mathrm{n}=4$. CSC, cancer stem cell; ALDH1A1, aldehyde dehydrogenase 1 family member A1; ALDH, aldehyde dehydrogenase; 5-FU, 5-fluorouracil; DEAB, diethylaminobenzaldehyde.

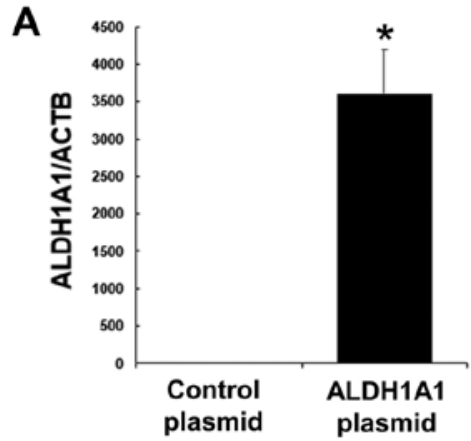

B
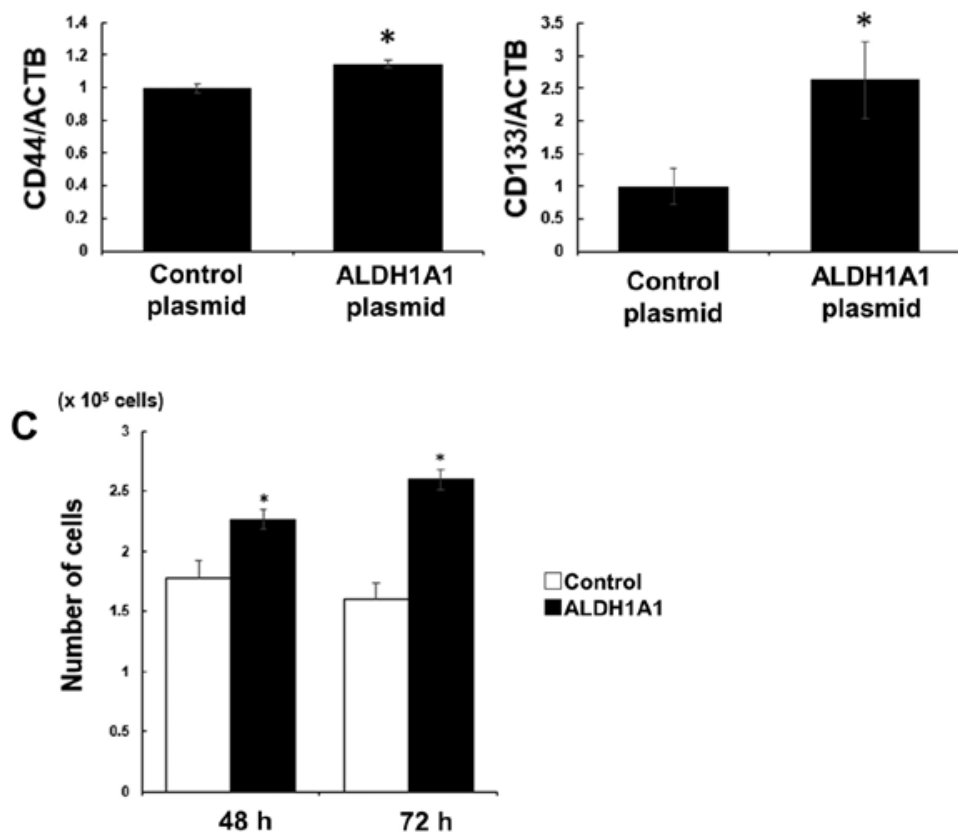

Figure 2. Effect of ALDH1A1 overexpression in PK59 cells. (A) The ALDH1A1 plasmid effectively increased ALDH1A1 mRNA levels in PK59 cells. $\mathrm{n}=3$. (B) CD44 and CD133 mRNA levels were significantly increased by the ALDH1A1 plasmid compared with those in cells transfected with the control plasmid. (C) The overexpression of ALDH1A1 promoted the proliferation of PK59 cells. Cell numbers were counted $72 \mathrm{~h}$ after ALDH1A1 plasmid transfection. $\mathrm{n}=4$. Data are presented as the mean \pm SEM. ${ }^{*} \mathrm{P}<0.05$ vs. control plasmid. ALDH1A1, aldehyde dehydrogenase 1 family member A1; ACTB, $\beta$-actin. 
A
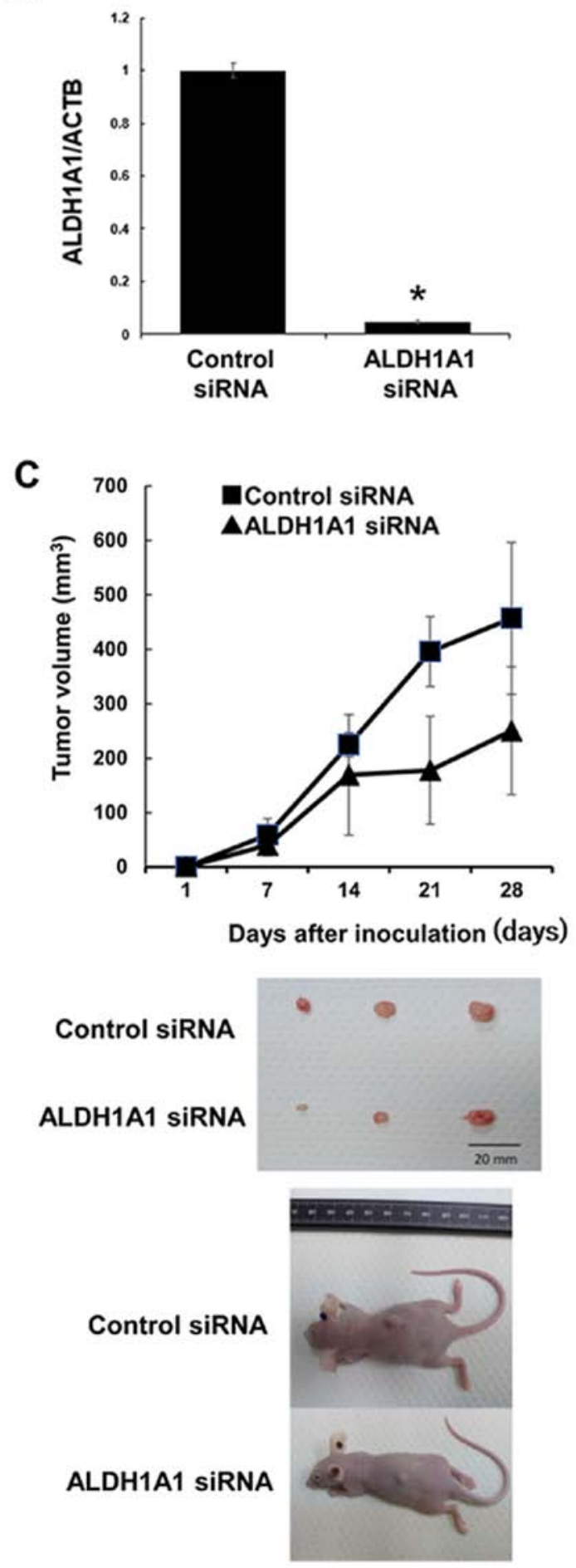

B

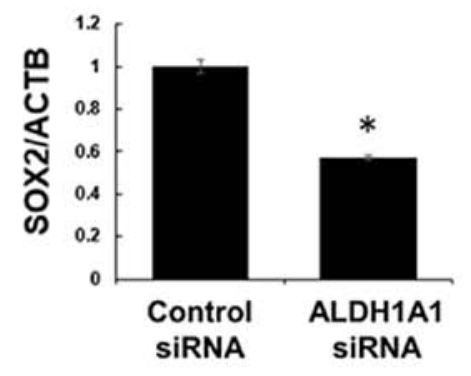

D

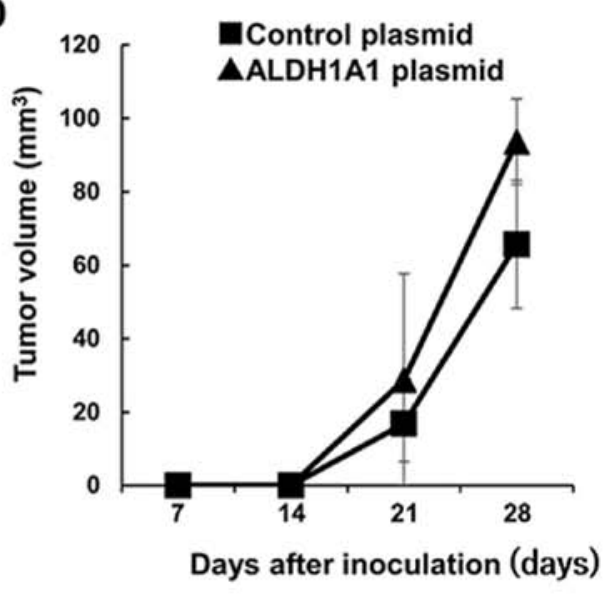

Control plasmid

ALDH1A1 plasmid

Control plasmid

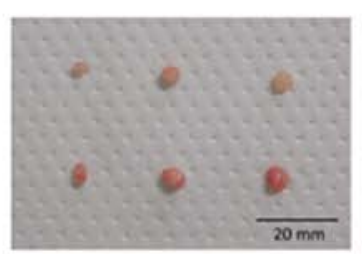

ALDH1A1 plasmid

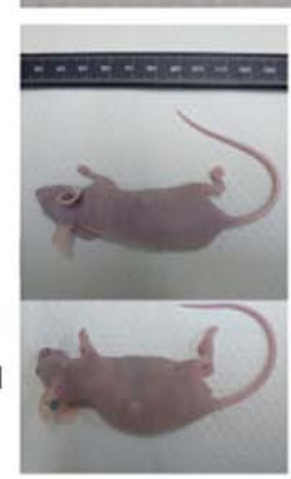

Figure 3. Effect of ALDH1A1 knockdown in PK59 cells. ALDH1A1 siRNA effectively reduced (A) ALDH1A1 and (B) SOX2 mRNA levels in PK59 cells. $\mathrm{n}=3$. ${ }^{*} \mathrm{P}<0.05$ vs. control siRNA. (C) A xenograft model in nude mice using PK59 cells transfected with ALDH1A1 siRNA. The volumes of resected tumors were slightly lower in the ALDH1A1 siRNA group compared with those in the control group. $n=3$. (D) A xenograft model in nude mice using PK59 cells transfected with the ALDH1A1 overexpression plasmid. The volumes of resected tumors were slightly higher in the ALDH1A1 plasmid group compared with those in the control plasmid group. $\mathrm{n}=3$. Data are presented as the mean \pm SEM. ALDH1A1, aldehyde dehydrogenase 1 family member A1; siRNA, small interfering RNA; ACTB, $\beta$-actin.

in Table SI. These results revealed the upregulated expression levels of CSC markers, such as SOX2, ALDH1A1 and CXCR4, in PK59 CSCs compared with those in non-CSCs (Table SII). The expression levels of ion channel-related genes in PK59 CSCs were further analyzed using IPA software; the expression levels of 57 genes associated with ion channels were upregulated in PK59 CSCs compared with those in non-CSCs (Table I).

The top-ranking genes related to potassium voltage-gated channels, based on fold change expression in the microarray results, were selected for further analysis. RT-qPCR was 
Table I. Ion channel-related genes with high expression levels in cancer stem cells isolated from PK59 cells.

\begin{tabular}{|c|c|c|c|}
\hline Gene symbol & UniGene ID & Gene name & Fold-change \\
\hline GJC1 & Hs.712052 & Gap junction protein $\gamma 1$ & 629.762 \\
\hline CACNA2D1 & Hs. 282151 & $\begin{array}{l}\text { Calcium voltage-gated channel auxiliary } \\
\text { subunit } \alpha 2 \delta 1\end{array}$ & 303.458 \\
\hline TMEM63C & Hs. 22452 & Transmembrane protein $63 \mathrm{C}$ & 234.969 \\
\hline KCTD4 & Hs.23406 & $\begin{array}{l}\text { Potassium channel tetramerization } \\
\text { domain-containing } 4\end{array}$ & 217.796 \\
\hline KCNB 1 & Hs.84244 & $\begin{array}{l}\text { Potassium voltage-gated channel } \\
\text { subfamily B member } 1\end{array}$ & 191.214 \\
\hline $\mathrm{HCN} 1$ & Hs.353176 & $\begin{array}{l}\text { Hyperpolarization-activated cyclic } \\
\text { nucleotide-gated potassium channel } 1\end{array}$ & 179.023 \\
\hline ANXA6 & Hs.412117 & Annexin A6 & 135.343 \\
\hline KCNG3 & Hs.352633 & $\begin{array}{l}\text { Potassium voltage-gated channel modifier } \\
\text { subfamily G member } 3\end{array}$ & 104.575 \\
\hline SCN9A & Hs.439145 & Sodium voltage-gated channel $\alpha$ subunit 9 & 83.685 \\
\hline MCOLN2 & Hs.591446 & Mucolipin 2 & 71.243 \\
\hline KCNF1 & Hs.23735 & $\begin{array}{l}\text { Potassium voltage-gated channel modifier } \\
\text { subfamily F member } 1\end{array}$ & 67.786 \\
\hline KCNG1 & Hs.118695 & $\begin{array}{l}\text { Potassium voltage-gated channel modifier } \\
\text { subfamily G member } 1\end{array}$ & 60.852 \\
\hline TRPM8 & Hs.366053 & $\begin{array}{l}\text { Transient receptor potential cation channel } \\
\text { subfamily M member } 8\end{array}$ & 60.393 \\
\hline TRPC1 & Hs.250687 & $\begin{array}{l}\text { Transient receptor potential cation channel } \\
\text { subfamily } \mathrm{C} \text { member } 1\end{array}$ & 55.342 \\
\hline SLC9A1 & Hs.469116 & Solute carrier family 9 member A1 & 39.349 \\
\hline GRIN2A & Hs.411472 & $\begin{array}{l}\text { Glutamate ionotropic receptor NMDA type } \\
\text { subunit } 2 \mathrm{~A}\end{array}$ & 37.432 \\
\hline TMEM150C & Hs.507676 & Transmembrane protein $150 \mathrm{C}$ & 37.276 \\
\hline MCOLN3 & Hs.535239 & Mucolipin 3 & 32.26 \\
\hline GABRD & Hs.113882 & $\gamma$-aminobutyric acid type A receptor $\delta$ subunit & 31.534 \\
\hline KCND1 & Hs.55276 & $\begin{array}{l}\text { Potassium voltage-gated channel } \\
\text { subfamily D member } 1\end{array}$ & 28.252 \\
\hline GRIK2 & Hs.98262 & $\begin{array}{l}\text { Glutamate ionotropic receptor kainate type } \\
\text { subunit } 2\end{array}$ & 24.759 \\
\hline $\mathrm{ZACN}$ & Hs.714919 & Zinc-activated ion channel & 22.824 \\
\hline SCN8A & Hs.710638 & Sodium voltage-gated channel $\alpha$ subunit 8 & 21.842 \\
\hline LRRC8C & Hs.412836 & Leucine-rich repeat-containing $8 \mathrm{VRAC}$ subunit $\mathrm{C}$ & 15.768 \\
\hline $\mathrm{KCNC} 1$ & Hs.552896 & $\begin{array}{l}\text { Potassium voltage-gated channel subfamily C } \\
\text { member } 1\end{array}$ & 15.316 \\
\hline CACNA1G & Hs.591169 & Calcium voltage-gated channel subunit $\alpha 1 \mathrm{G}$ & 14.324 \\
\hline $\mathrm{KCNH} 1$ & Hs.553187 & $\begin{array}{l}\text { Potassium voltage-gated channel subfamily } \mathrm{H} \\
\text { member } 1\end{array}$ & 10.901 \\
\hline CACNA1H & Hs.459642 & Calcium voltage-gated channel subunit $\alpha 1 \mathrm{H}$ & 10.788 \\
\hline GRIN3B & Hs.660378 & $\begin{array}{l}\text { Glutamate ionotropic receptor NMDA type } \\
\text { subunit 3B }\end{array}$ & 10.067 \\
\hline CACNA1I & Hs.125116 & Calcium voltage-gated channel subunit $\alpha 1$ I & 9.816 \\
\hline TTYH2 & Hs.27935 & Tweety family member 2 & 9.742 \\
\hline KCNMA1 & Hs.144795 & $\begin{array}{l}\text { Potassium calcium-activated channel } \\
\text { subfamily } \mathrm{M} \alpha 1\end{array}$ & 9.038 \\
\hline KCNK13 & Hs.510191 & $\begin{array}{l}\text { Potassium two pore domain channel subfamily K } \\
\text { member } 13\end{array}$ & 8.942 \\
\hline CACNG4 & Hs.514423 & $\begin{array}{l}\text { Calcium voltage-gated channel auxiliary } \\
\text { subunit } \gamma 4\end{array}$ & 8.593 \\
\hline
\end{tabular}


Table I. Continued.

\begin{tabular}{|c|c|c|c|}
\hline Gene symbol & UniGene ID & Gene name & Fold-change \\
\hline KCNE2 & Hs.551521 & $\begin{array}{l}\text { Potassium voltage-gated channel subfamily E } \\
\text { regulatory subunit } 2\end{array}$ & 8.265 \\
\hline KCNMB3 & Hs.591285 & $\begin{array}{l}\text { Potassium calcium-activated channel subfamily } M \\
\text { regulatory } \beta \text { subunit } 3\end{array}$ & 8.138 \\
\hline $\mathrm{HCN} 4$ & Hs.86941 & $\begin{array}{l}\text { Hyperpolarization-activated cyclic nucleotide-gated } \\
\text { potassium channel } 4\end{array}$ & 7.770 \\
\hline CLCN5 & Hs. 166486 & Chloride voltage-gated channel 5 & 7.703 \\
\hline CACNA1A & Hs. 501632 & Calcium voltage-gated channel subunit $\alpha 1 \mathrm{~A}$ & 7.116 \\
\hline АВСС9 & Hs.732701 & ATP-binding cassette subfamily $\mathrm{C}$ member 9 & 7.108 \\
\hline GPM6A & Hs.75819 & Glycoprotein M6A & 6.524 \\
\hline KCTD13 & Hs. 534590 & $\begin{array}{l}\text { Potassium channel tetramerization } \\
\text { domain-containing } 13\end{array}$ & 6.269 \\
\hline ASIC1 & Hs.274361 & Acid-sensing ion channel subunit 1 & 5.888 \\
\hline CACNA2D2 & Hs. 476273 & $\begin{array}{l}\text { Calcium voltage-gated channel auxiliary } \\
\text { subunit } \alpha 2 \delta 2\end{array}$ & 5.886 \\
\hline KCNQ2 & Hs.161851 & $\begin{array}{l}\text { Potassium voltage-gated channel subfamily Q } \\
\text { member } 2\end{array}$ & 5.540 \\
\hline KCNT1 & Hs.104950 & $\begin{array}{l}\text { Potassium sodium-activated channel subfamily } \mathrm{T} \\
\text { member } 1\end{array}$ & 5.086 \\
\hline PKDREJ & Hs. 241383 & Polycystin family receptor for egg jelly & 5.076 \\
\hline KCNK12 & Hs.591586 & $\begin{array}{l}\text { Potassium two pore domain channel subfamily } \mathrm{K} \\
\text { member } 12\end{array}$ & 4.632 \\
\hline ITPR1 & Hs.567295 & Inositol 1,4,5-trisphosphate receptor type 1 & 4.594 \\
\hline CACNB4 & Hs.120725 & Calcium voltage-gated channel auxiliary subunit $\beta 4$ & 4.450 \\
\hline CNGA4 & Hs.434618 & Cyclic nucleotide-gated channel $\alpha 4$ & 4.342 \\
\hline CLCA4 & Hs.567422 & Chloride channel accessory 4 & 4.080 \\
\hline KCNQ1 & Hs.95162 & $\begin{array}{l}\text { Potassium voltage-gated channel subfamily Q } \\
\text { member } 1\end{array}$ & 3.529 \\
\hline TRPV2 & Hs.279746 & $\begin{array}{l}\text { Transient receptor potential cation channel } \\
\text { subfamily V member } 2\end{array}$ & 3.415 \\
\hline SCN3B & Hs.4865 & Sodium voltage-gated channel $\beta$ subunit 3 & 3.412 \\
\hline GRINA & Hs.594634 & $\begin{array}{l}\text { Glutamate ionotropic receptor NMDA type } \\
\text { subunit-associated protein } 1\end{array}$ & 3.196 \\
\hline CLCN3 & Hs.481186 & Chloride voltage-gated channel 3 & 3.168 \\
\hline
\end{tabular}

conducted to validate the results obtained in the microarray analysis. In PK59 cells, KCNB1, KCNC1 and KCND1 mRNA expression levels were significantly higher in CSCs compared with those in non-CSCs (Fig. 4A). These results demonstrated that ion channels, which are involved in maintaining CSCs, exhibited high expression levels. Among these ion channels, KCNB1 was selected, and it was found that blocking this channel with 4-AP inhibited the proliferation of PK59 cells, which was suggested that inhibition of KCNB1 could be a potential therapeutic target for pancreatic cancer. Even after five passages, the high mRNA expression levels of $\mathrm{Kv}$ and CSC markers were maintained in PK59 CSCs (Fig. 5A and B). These results demonstrated the constant high expression of $\mathrm{Kv}$ in CSCs, which reinforced the possibility that $\mathrm{Kv}$ may be a therapeutic target for pancreatic cancer.
Effects of 4-AP on CSCs. The present study subsequently analyzed the overexpression of Kv in PK59 CSCs. To clarify the effects of the inhibition of Kv, PK59 non-CSCs and CSCs cells were both treated with 4-AP. Among PK59 cells, $\mathrm{IC}_{50}$ values were approximately 5.65 and $0.64 \mathrm{mM}$ in non-CSCs and CSCs, respectively (Fig. 4B and C). Therefore, the cytotoxicity of 4-AP appeared to be greater in CSCs compared with that in non-CSCs. A sphere formation assay was further performed using PK59 CSCs treated with or without 4-AP. The number of spheres formed by the PK59 CSCs was significantly lower in cells treated with 4-AP (Fig. 6). When non-CSCs (PK59 cell line) were treated with 4-AP, the population of cells strongly expressing ALDH1A1 significantly reduced compared with that in the control group (Fig. 7). Therefore, 4-AP specifically inhibited the activity of CSCs strongly expressing Kv. Overexpression experiments on PK59 cells using a KCNB1 
A
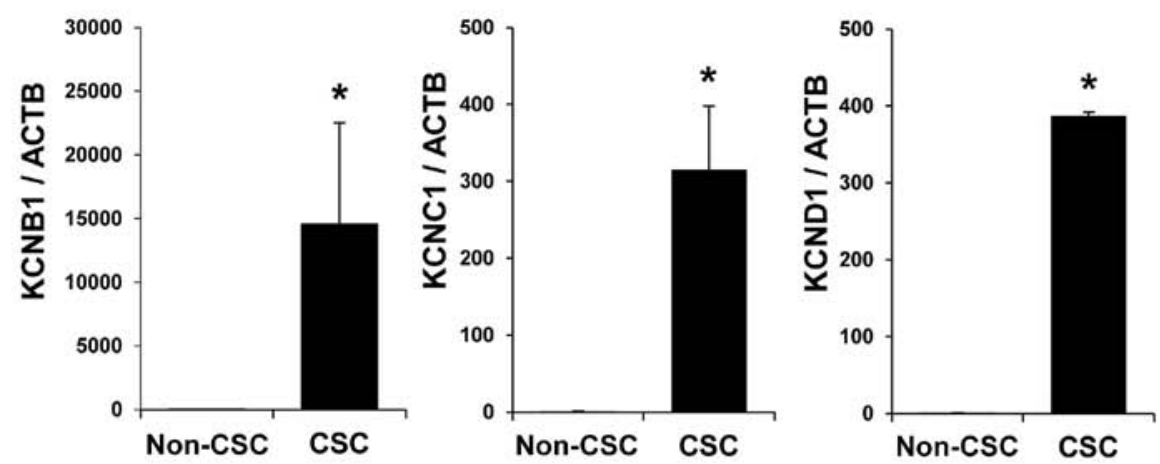

B
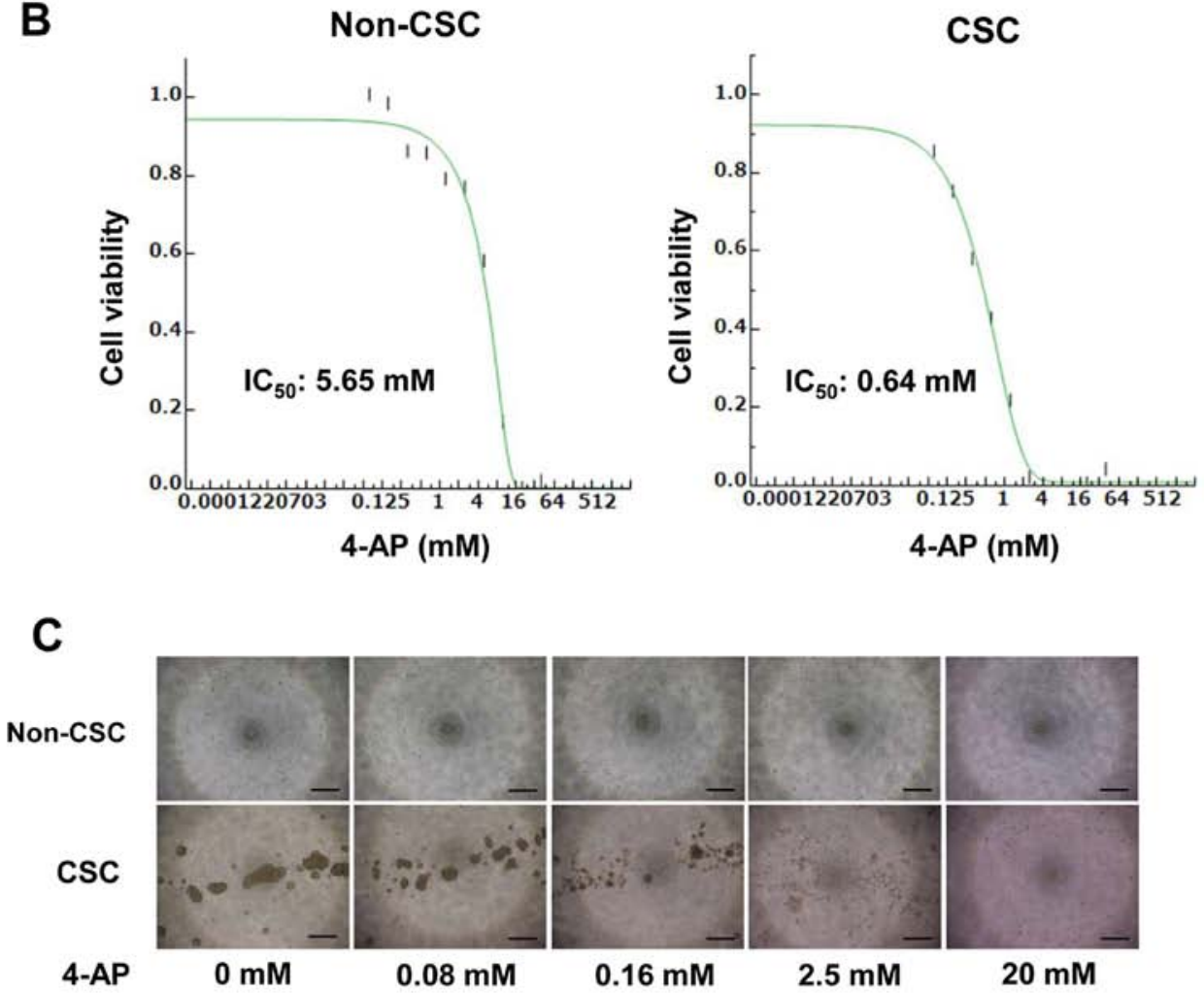

Figure 4. Verification of gene expression and drug sensitivity of non-CSCs or CSCs. (A) Verification of gene expression by RT-qPCR. The expression levels of three selected $\mathrm{Kv}$-related genes, $\mathrm{KCNB} 1, \mathrm{KCNC1}$ and $\mathrm{KCND} 1$, in CSCs were compared with those in the non-CSCs of PK59 cells using RT-qPCR. $\mathrm{n}=3$. ${ }^{*} \mathrm{P}<0.05$ vs. non-CSCs. (B) Drug sensitivity of CSCs to the Kv inhibitor 4-AP. 4-AP was more cytotoxic at a lower concentration in CSCs compared with non-CSCs isolated from PK59 cells. $\mathrm{n}=4$. (C) Representative images of cultured non-CSCs or CSCs treated with various concentrations of 4-AP Magnification, $\mathrm{x} 40$. Scale bar, $250 \mu \mathrm{m}$. Data are presented as the mean \pm SEM. Kv, voltage-gated potassium channel; 4-AP, 4-aminopyridine; RT-qPCR, reverse transcription-quantitative PCR; KCN, potassium voltage-gated channel; KCNB1, KCN subfamily B member 1; KCNC1, KCN subfamily C member 1; KCND1, KCN subfamily D member 1 ; CSCs, cancer stem cells; ACTB, $\beta$-actin.

plasmid were conducted in order to investigate its effects on cell proliferation and the function of Kv in PCSCs. KCNB1 mRNA levels in PK59 cells were markedly increased by KCNB1 plasmid transfection compared with those in cell transfected with the control plasmid (Fig. 8A). The number of KCNB1 plasmid-transfected PK59 cells was significantly higher compared with that of the control cells at $72 \mathrm{~h}$ post-transfection (Fig. 8B). The effects of 4-AP or 5-FU on cell proliferation were then assessed, and the results demonstrated that the number of 4-AP- or 5-FU-treated cells was significantly lower compared with that of untreated control cells (Fig. S2). Co-treatment with 4-AP and 5-FU revealed that 4-AP enhanced the inhibitory effects of 5-FU (Fig. S2).
Regarding the molecular mechanisms by which $\mathrm{Kv}$ maintains stemness and cell proliferation, the present study focused on changes in the intracellular ion environment. Our previous studies reported the roles of intracellular $\mathrm{Cl}^{-}$in cancer cell proliferation (28-31); thus, we hypothesized that the inhibition of $\mathrm{K}^{+}$channels by siRNA or 4-AP may affect the movement of $\mathrm{Cl}^{-}$, which is the counter ion of $\mathrm{K}^{+}(24)$. This hypothesis was tested by measuring the fluorescence intensity of MQAE, a $\mathrm{Cl}^{-}$-sensitive fluorescent probe, to evaluate the intracellular ion concentration (Fig. 9). The results revealed that the fluorescence intensity of MQAE was increased by the knockdown of KCNB1 or the treatment with 4-AP in PK59 cells compared with that in the corresponding control groups 
A
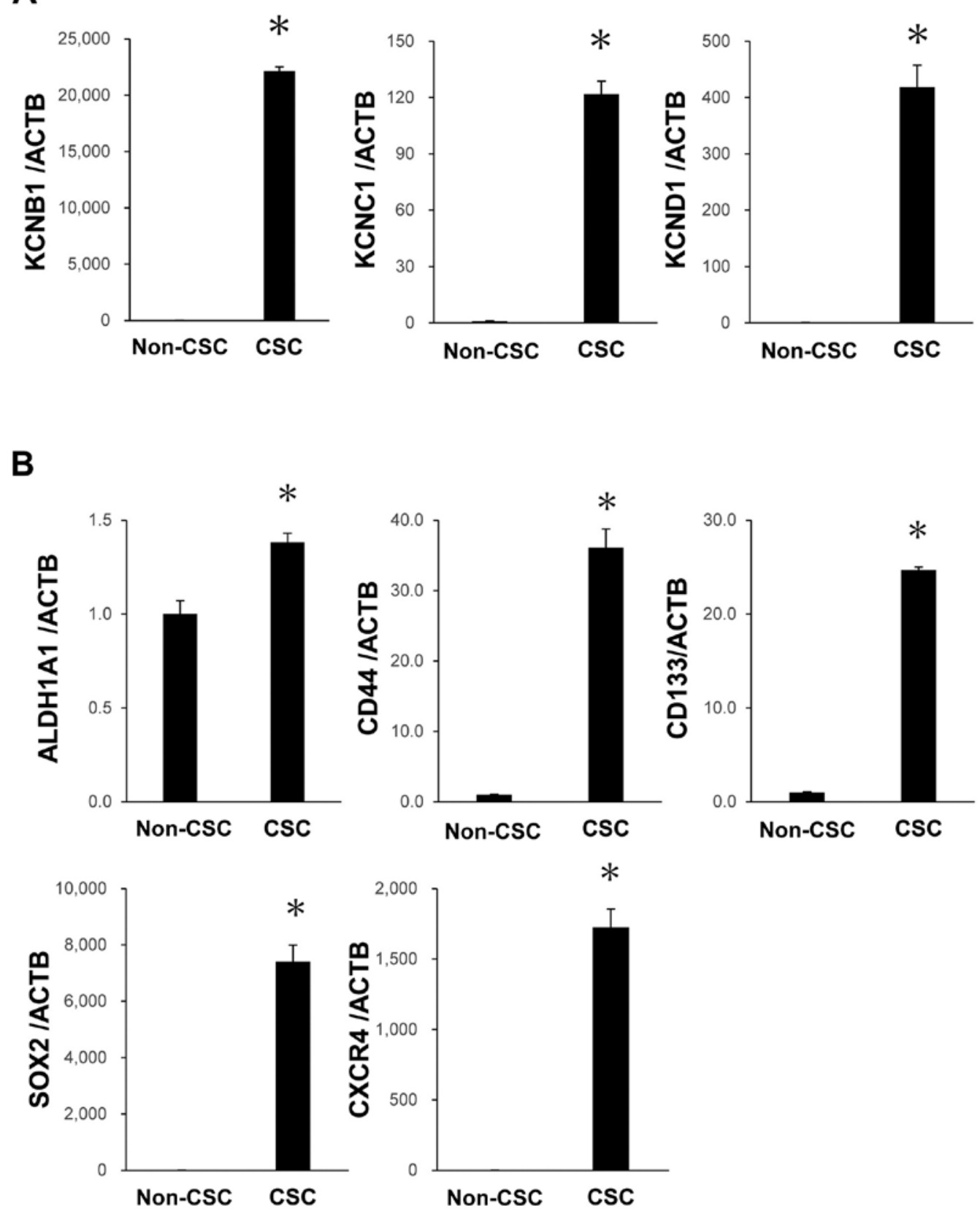

Figure 5. Expression levels of Kv and CSC markers in PK59 CSCs after five passages. (A) High mRNA expression levels of KCNB1, KCNC1 and KCND1 were maintained in PK59 CSCs. (B) High mRNA expression levels of ALDH1A1, CD44, CD133, SOX2 and CXCR4 were maintained in PK59 CSCs. mRNA expression levels were analyzed using reverse transcription-quantitative PCR. $n=3$. Data are presented as the mean \pm SEM. " $\mathrm{P}<0.05$ vs. non-CSCs. $\mathrm{Kv}$, voltage-gated potassium channel; KCN, potassium voltage-gated channel; KCNB1, KCN subfamily B member 1; KCNC1, KCN subfamily C member 1; KCND1, KCN subfamily D member 1 ; CSC, cancer stem cell; ACTB, $\beta$-actin.

(Fig. 9B and C). These results suggested that the change in intracellular $\mathrm{Cl}^{-}$induced by $\mathrm{Kv}$ may serve a key role in the molecular mechanisms underlying the regulation of stemness and cell proliferation.

The present study also examined the effects of the inhibition of $\mathrm{Kv}$ on tumor growth in vivo. PK59 cells incubated with or without 4-AP for $48 \mathrm{~h}$ were subcutaneously injected into nude mice, and the growth of tumor nodules was assessed (Fig. 10). Tumor volumes were significantly lower in the sites injected with PK59 cells treated with 4-AP compared with those formed by untreated cells (Fig. 10). The levels of CSC markers in tumor tissues were further analyzed. The number of ALDH1A1-stained cells in tumors formed by 4-AP-treated PK59 cells was markedly lower compared with those formed by the untreated cells (Fig. 11A). Furthermore, ALDH1A1 mRNA levels were significantly lower in tumors treated with 4-AP compared with those formed by the untreated cells (Fig. 11B). Tumor weights were also significantly lower in mice injected with PK59 cells treated with 4-AP combined with 5-FU compared with those in mice inoculated with cells treated with 5-FU alone (Fig. 12). These results suggested that the inhibition of Kv with 4-AP strongly suppressed the development of pancreatic tumors in vivo. 
A

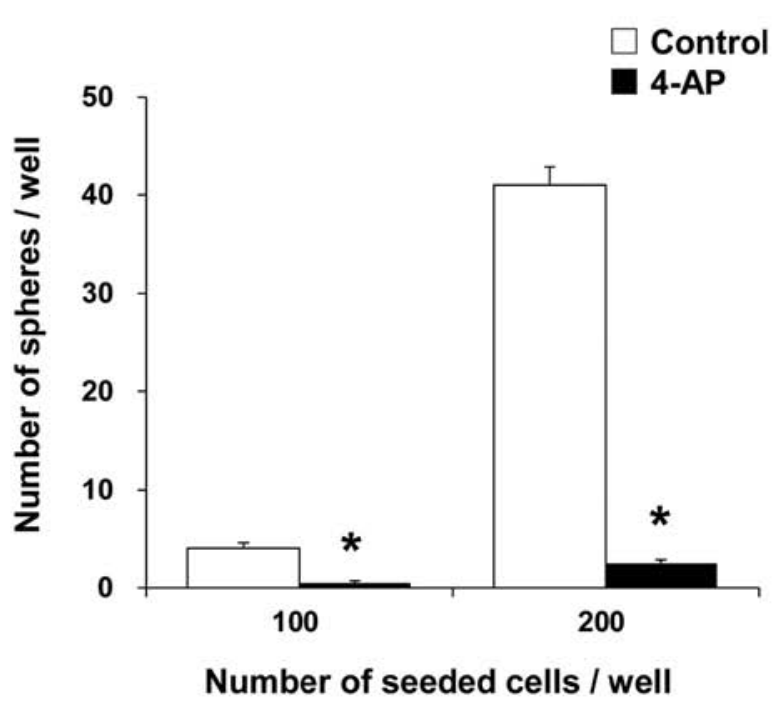

B

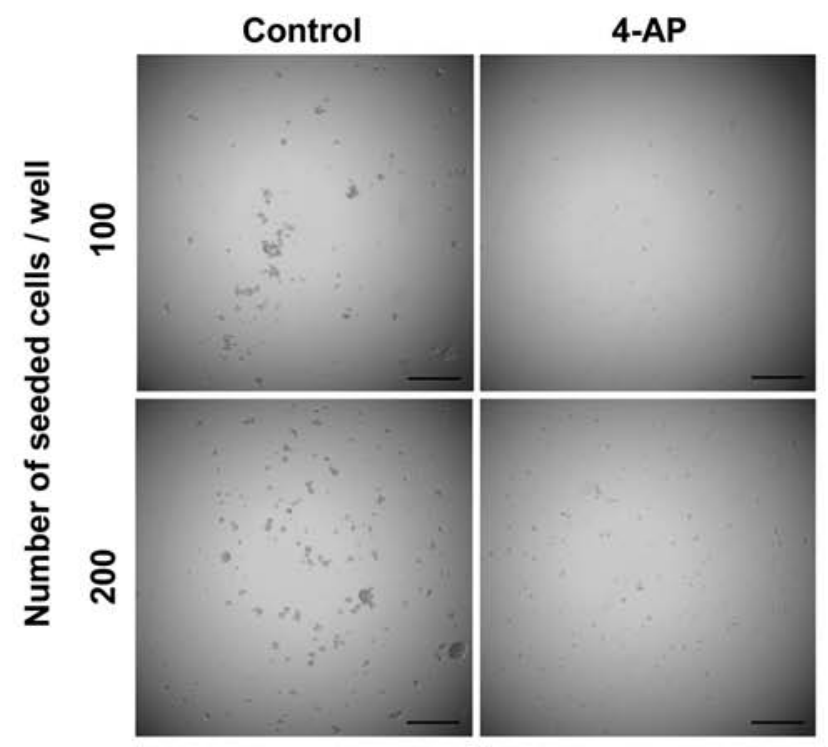

Figure 6. Effects of 4-AP on sphere formation by CSCs. (A) Treatment with $5 \mathrm{mM} 4$-AP decreased the number of spheres in the CSCs isolated from PK59 cells compared with those in untreated CSCs. Data are presented as the mean \pm SEM. $n=6$. * $\mathrm{P}<0.05$ vs. control. (B) Representative images of cultured CSCs treated with or without 4-AP. Magnification, $\mathrm{x} 40$. Scale bar, $500 \mu \mathrm{m}$. The concentration of 4 -AP was based on the IC ${ }_{50}$. CSCs, cancer stem cells; 4 -AP, 4-aminopyridine.
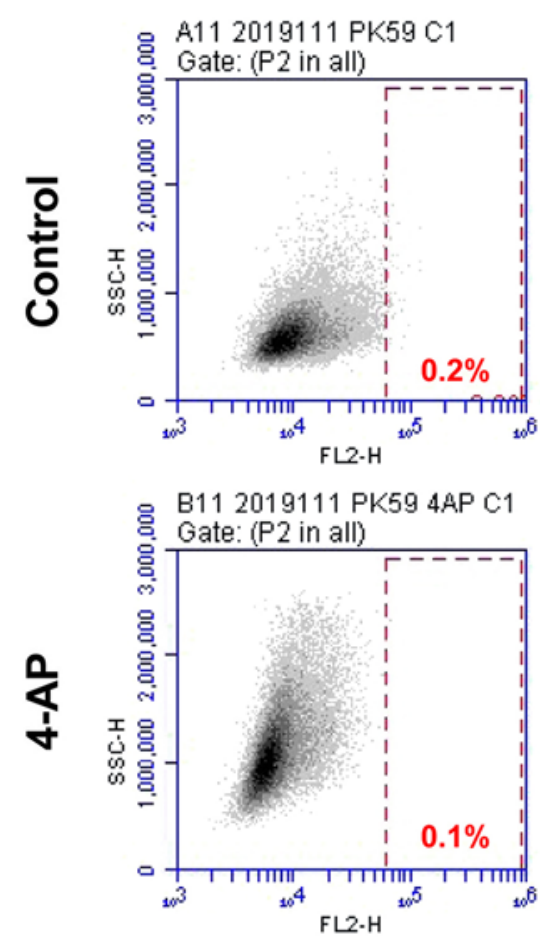

Aldefluor+DEAB
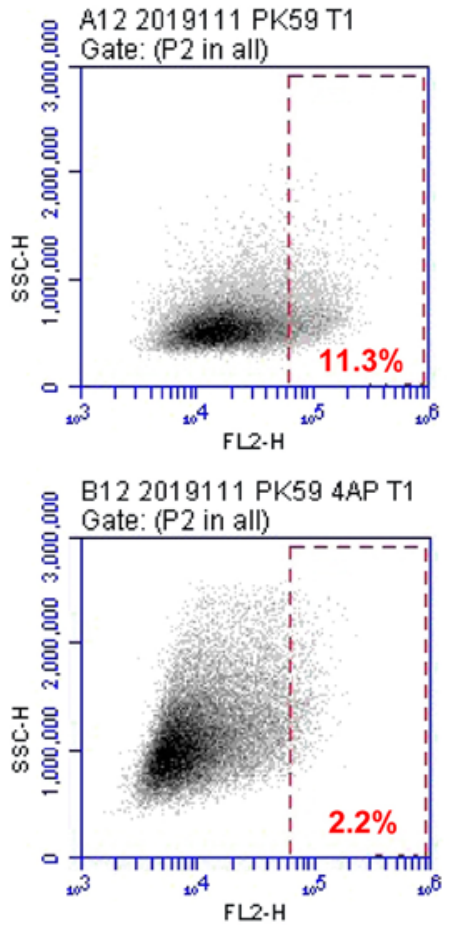

Aldefluor

Figure 7. Effects of 4-AP on ALDH1A1 expression by non-CSCs. Treatment with $5 \mathrm{mM}$ 4-AP for $48 \mathrm{~h}$ decreased the percentage of cells expressing high levels of ALDH1A1, as demonstrated by flow cytometry with Aldefluor staining. Data are presented as the mean \pm SEM. $n=3$. * $P<0.05$ vs. control. $4-A P$, 4-aminopyridine; ALDH1A1, aldehyde dehydrogenase 1 family member A1; CSC, cancer stem cell; DEAB, diethylaminobenzaldehyde.

Correlation analysis between ALDHIAl and KCNBI in databases. Analysis using the cBioPortal database revealed that the expression levels of ALDH1A1 and KCNB1 are positively correlated in primary tumor samples of human pancreatic cancer (Fig. 13).

\section{Discussion}

Previous studies have demonstrated that several CSC-specific markers are present in pancreatic cancer, including ALDH1, CD133, CD24, CD44, CXCR4, EpCAM, ABCG2, c-Met 
A

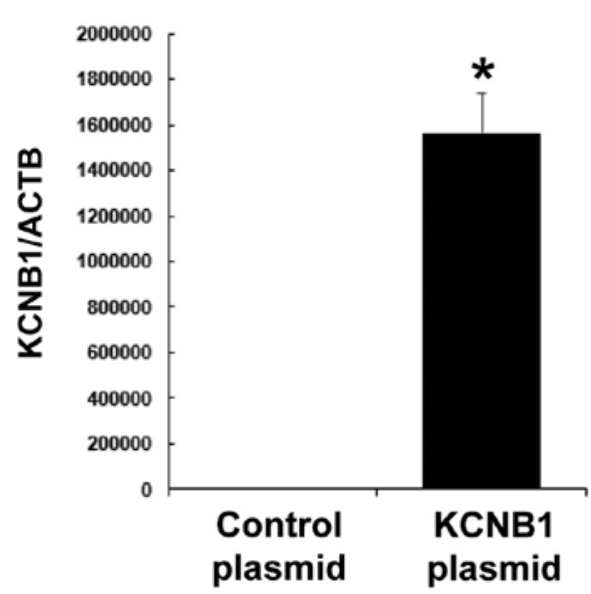

B

( $\times 10^{5}$ cells)

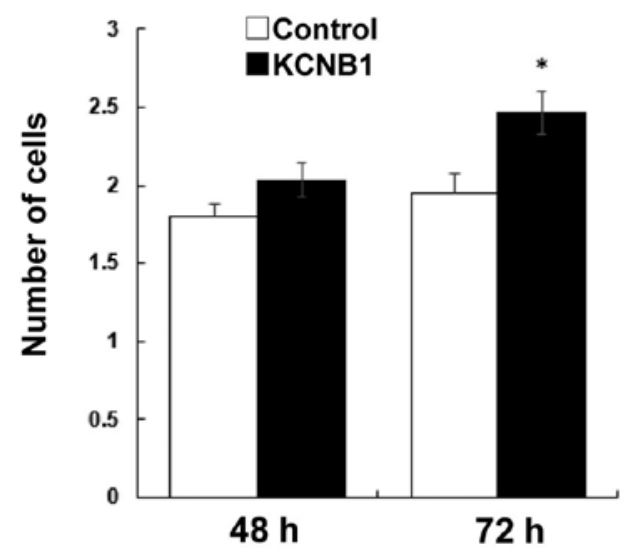

Figure 8. Effect of KCNB1 overexpression in PK59 cells. (A) The KCNB1 plasmid effectively increased KCNB1 mRNA levels in PK59 cells. $\mathrm{n}=3$. (B) The overexpression of KCNB1 promoted the proliferation of PK59 cells. The number of cells was counted $72 \mathrm{~h}$ post-KCNB1 plasmid transfection. $\mathrm{n}=4$. Data are presented as the mean $\pm \mathrm{SEM}$. ${ }^{*} \mathrm{P}<0.05$ vs. control plasmid. KCNB1, potassium voltage-gated channel subfamily B member 1; ACTB, $\beta$-actin.

A

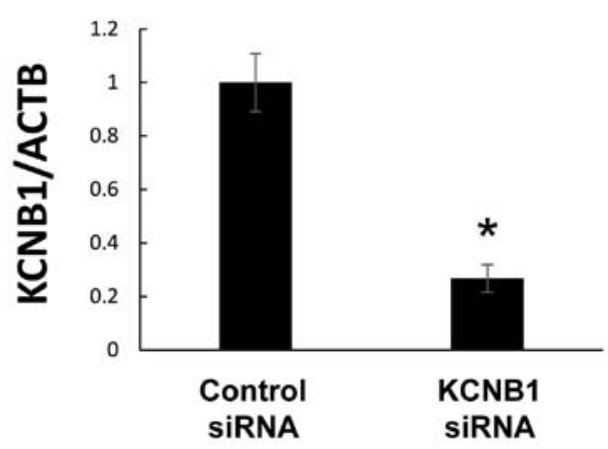

B
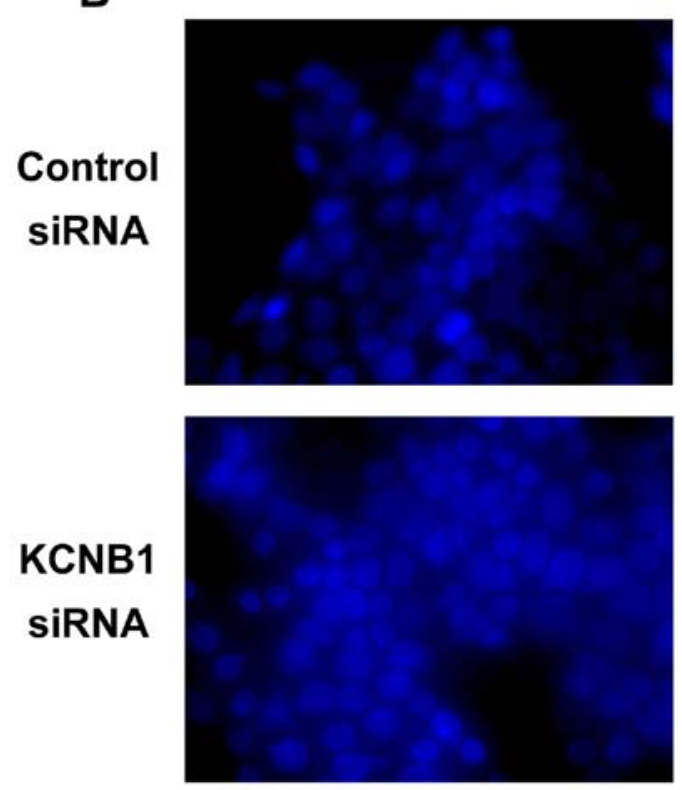

C

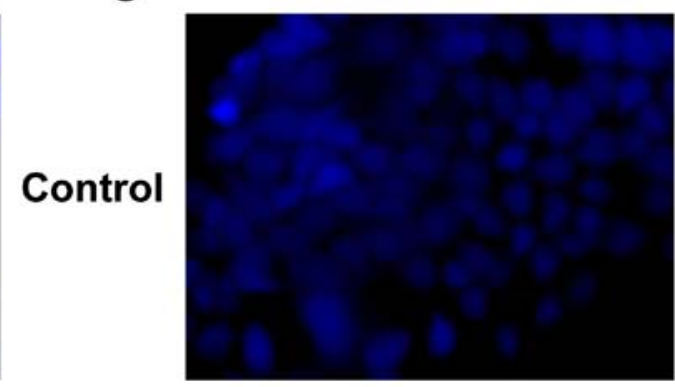

4-AP

Figure 9. Analysis of intracellular Cl- levels using MQAE reagent, a $\mathrm{Cl}^{-}$-sensitive fluorescence probe. (A) KCNB1 siRNA markedly decreased KCNB1 mRNA levels in PK59 cells. Data are presented as the mean \pm SEM. $n=3$. ${ }^{*} \mathrm{P}<0.05$ vs. control siRNA. (B) The depletion of KCNB1 using siRNA increased the fluorescence intensity of MQAE in PK59 cells. (C) The treatment with 4-AP inhibited the increased fluorescence intensity of MQAE in PK59 cells. KCNB1, potassium voltage-gated channel subfamily B member 1 ; siRNA, small interfering RNA; ACTB, $\beta$-actin; 4-AP, 4-aminopyridine. 

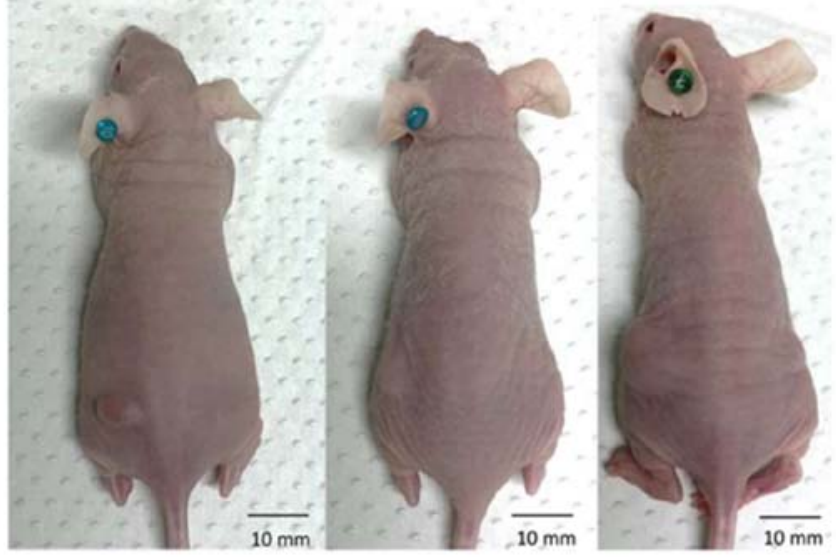

\section{Control}

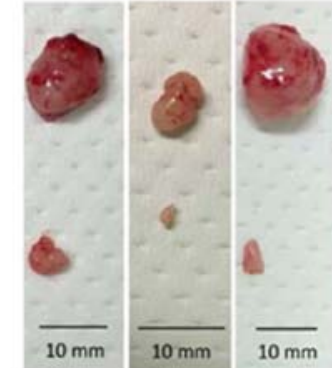

B

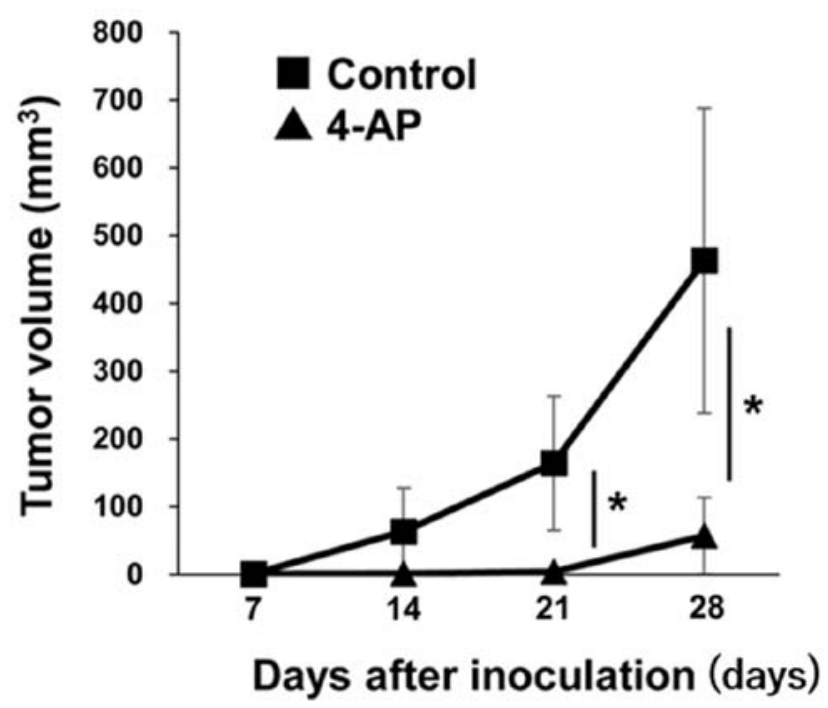

Figure 10. PK59 cells incubated with 4-AP exhibit reduced tumor growth in a mouse xenograft model. Suspensions of $5 \times 10^{5} \mathrm{PK} 59$ cells incubated with $5 \mathrm{mM}$ 4-AP for $48 \mathrm{~h}$ were injected subcutaneously into the right side of the lower flanks of 4-week-old female nude mice, and suspensions with the same amount of PK59 cells incubated without 4-AP were injected into the left side. (A) Images of tumors formed by PK59 cells incubated with or without 4-AP in mice. Tumors from PK59 cells treated with 4-AP were smaller compared with the control tumors. (B) The volumes of resected tumors were significantly lower in the 4-AP group compared with those in the control group. Data are presented as the mean \pm SEM. $n=3$. ${ }^{P}<0.05$ vs. control. 4-AP, 4-aminopyridine.

and nestin $(4,26,27)$. In addition, the high expression level of ALDH1 is associated with tumorigenic cells in pancreatic ductal adenocarcinoma (32-35). Aldefluor has been successfully applied to detect enhanced ALDH1 activity and isolate CSCs from pancreatic cancer cells $(33,35)$. In the present study, the Aldefluor assay was used to isolate and obtain PCSCs following tumorsphere formation. The obtained results demonstrated that PCSCs strongly expressed ALDH1A1, exhibited the capacity to redifferentiate and were resistant to chemotherapy. Gene expression data confirmed the upregulated expression of 57 genes in ion channels in PK59 CSCs, indicating the potential efficacy of selective ion channel inhibitors as a targeted treatment against CSCs. Among these genes, the role and function of $\mathrm{K}^{+}$channels in CSCs were subjected to further analysis. The Aldefluor assay was performed using various cell lines, including PANC1, PK1, PK45H, PK59, KP4-1, AsPC1 and SUIT-2. Cells that strongly expressed ALDH1A1 with FACS were isolated from four cell lines, including PK59, PANK1, PK4-1 and SUIT-2. However, tumorspheres were only obtained from cells isolated from PK59, and thus, CSCs from one cell line were examined in the present study. Our previous study demonstrated that several $\mathrm{K}^{+}$channels were upregulated in CSCs from esophageal squamous cell carcinoma (20), suggesting that similar transporters may be expressed in other PCSCs.

$\mathrm{K}^{+}$channels serve a key role in multiple cellular functions, such as the regulation of cell volume, differentiation, proliferation, migration and apoptosis (36-38). $\mathrm{K}^{+}$channels may be classified according to several criteria, including the stimulus to which they respond and their biophysical and structural properties, into the following four main families: $\mathrm{Kv}$, calcium-activated $\mathrm{K}^{+}$channels, inward-rectifier $\mathrm{K}^{+}$channels and two-pore-domain $\mathrm{K}^{+}$channels $(36,38) . \mathrm{Kv}$ are selectively permeable to $\mathrm{K}^{+}$ions and comprise a large family of heterogeneous groups of ion channels forming 12 subfamilies (Kv1-Kv12) (36-38). Kv are widely distributed in a number of cancer cell types, and their oncogenic potential has been documented $(36,38)$. Kv are also potential molecular targets for anticancer therapies, and their 
A

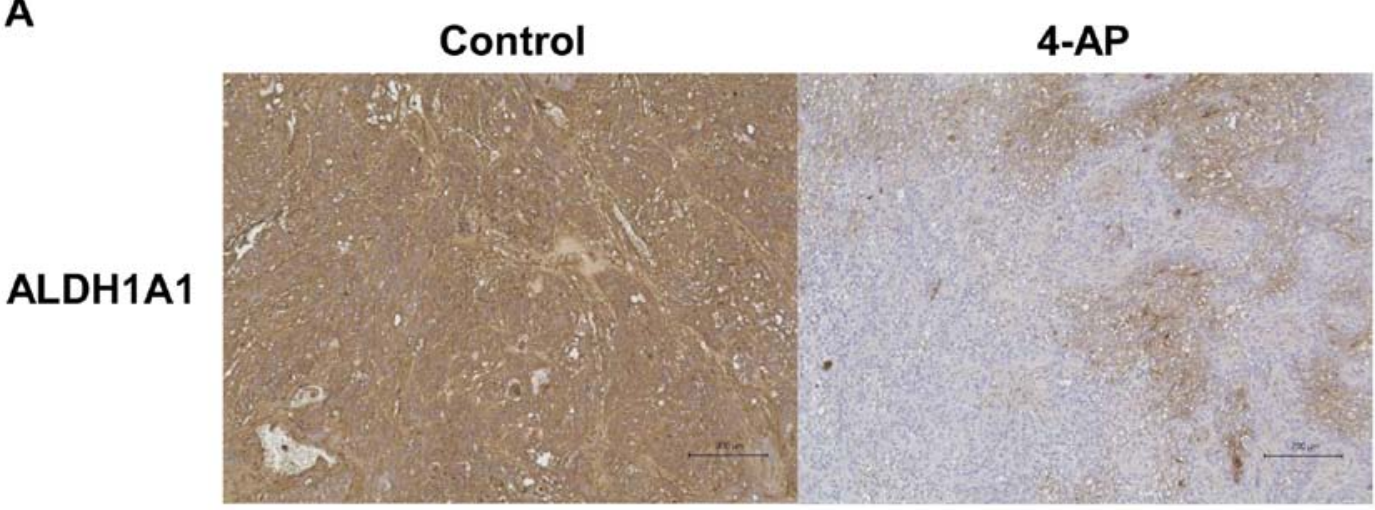

B

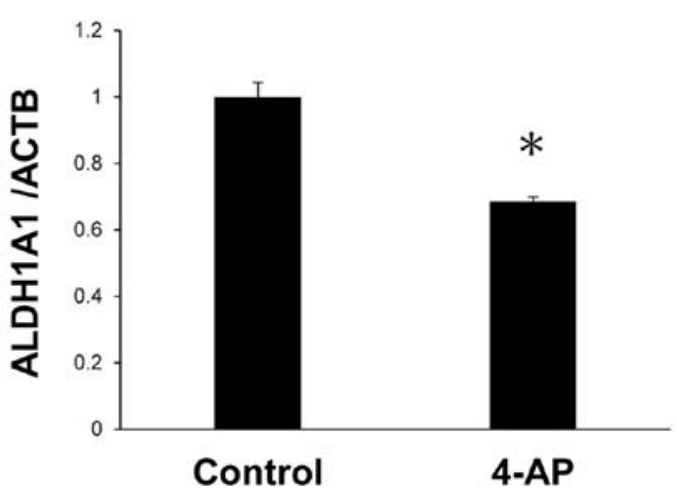

Figure 11. CSC marker expression in tumor tissue. (A) The number of ALDH1A1-stained cells in the tumors of mice injected with PK59 cells treated with 4-AP was markedly lower compared with those in the control group. Magnification, x100. Scale bar, $200 \mu \mathrm{m}$. (B) ALDH1A1 mRNA levels were significantly lower in tumors treated with 4 -AP compared with those in the control group. Data are presented as the mean \pm SEM. $n=3$. ${ }^{*} \mathrm{P}<0.05 \mathrm{vs}$. control. CSC, cancer stem cell; ALDH1A1, aldehyde dehydrogenase 1 family member A1; 4-AP, 4-aminopyridine; ACTB, $\beta$-actin.

A

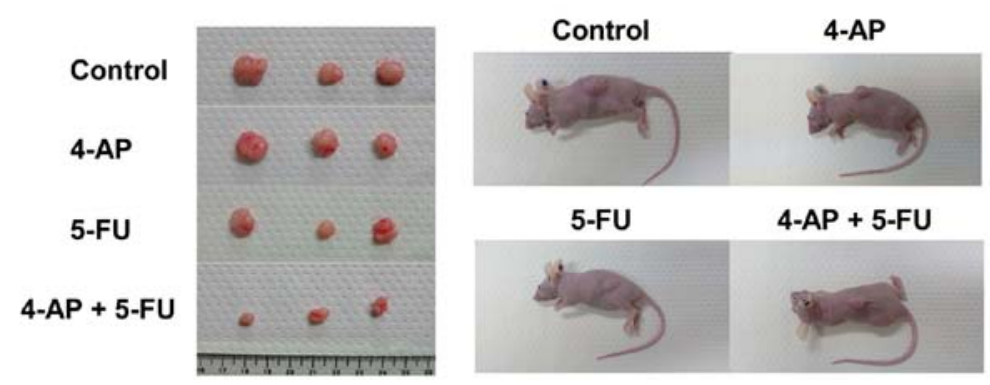

B

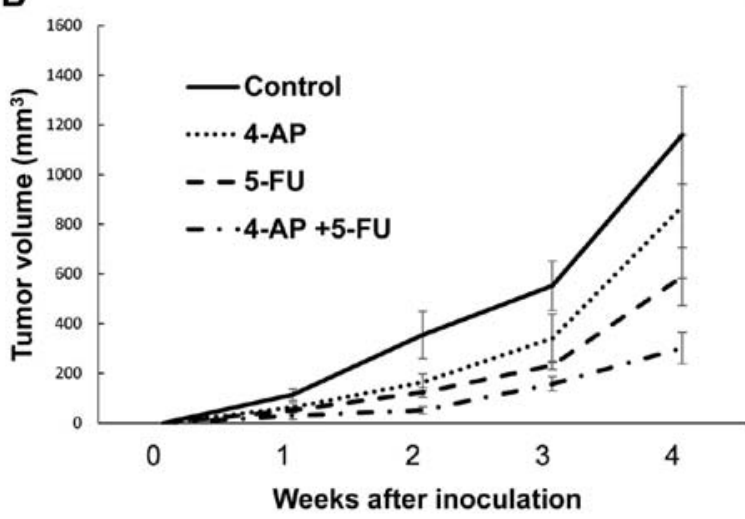

C

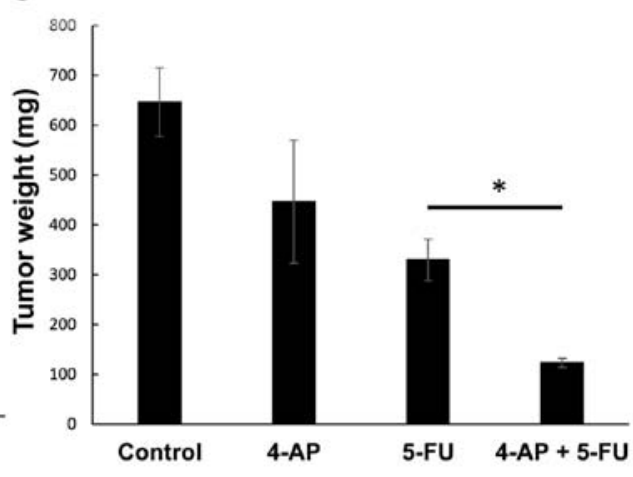

Figure 12. Tumor growth from PK59 cells treated with 4-AP, 5-FU or 5-FU combined with 4-AP in a nude mouse xenograft model. Suspensions of 5x $10^{5}$ PK59 cells incubated with $2 \mathrm{mM} 4$-AP, $4 \mu \mathrm{M}$ 5-FU or 5-FU combined with 4-AP for $48 \mathrm{~h}$ were injected subcutaneously into the lower flanks of 4-week-old female nude mice. (A) Images of tumors formed by PK59 cells incubated 4-AP, 5-FU or 5-FU combined with 4-AP in mice. (B) The volumes of tumors in mice. $\mathrm{n}=3$. (C) Resected tumor weights. Tumor weights were significantly lower in mice injected with PK59 cells treated with 4-AP combined with 5-FU compared with those treated with 5-FU alone. Data are presented as the mean \pm SEM. $n=3$. ${ }^{*} \mathrm{P}<0.05$; 4-AP, 4-aminopyridine; 5-FU, 5-fluorouracil. 


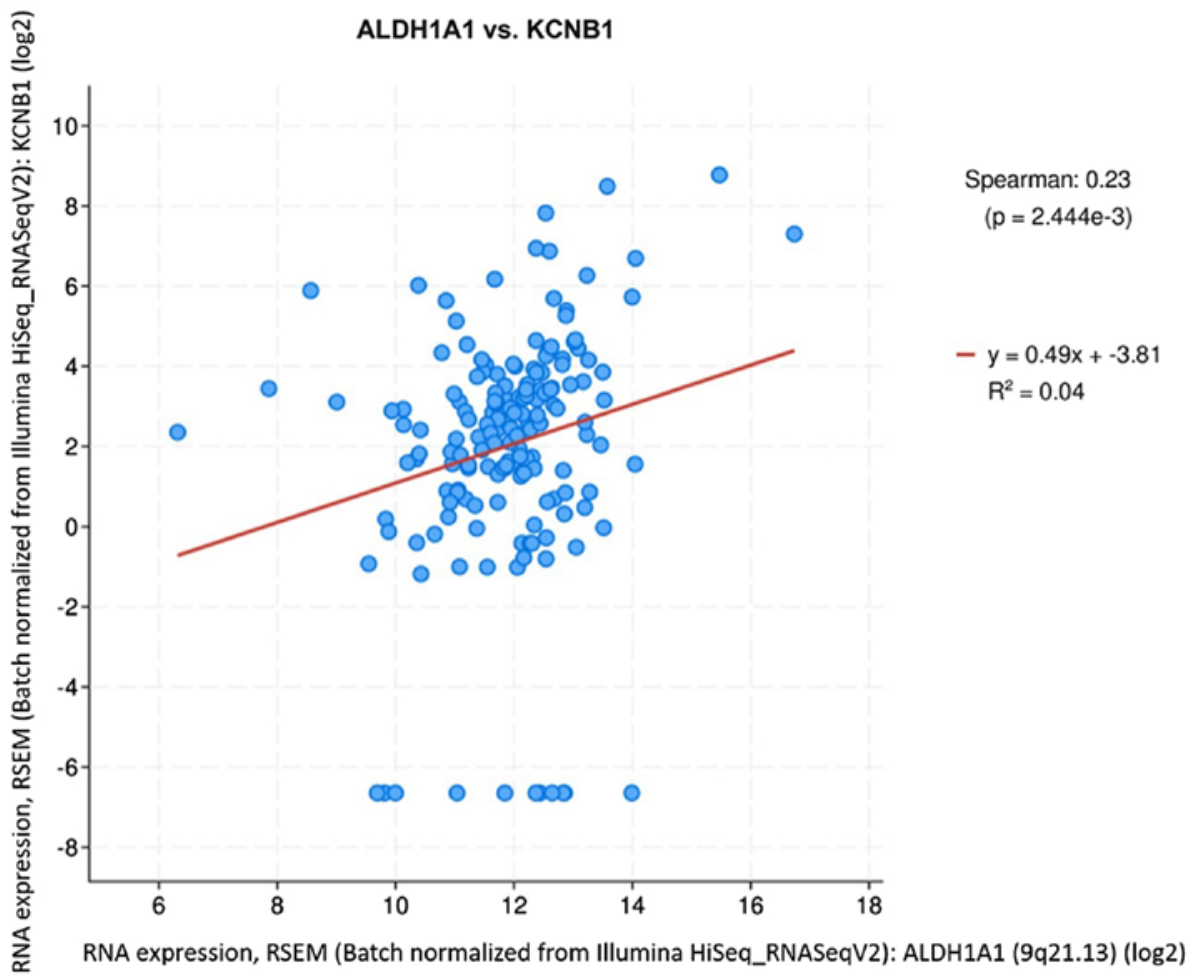

Figure 13. Correlation between ALDHA1A and KCNB1 mRNA expression levels in human pancreatic cancer in the cBioPortal database. ALDH1A1, aldehyde dehydrogenase 1 family member A1; KCNB1, potassium voltage-gated channel subfamily B member 1 .

blockers and antibodies have been investigated and used in previous studies (38). In pancreatic cancer cells, epigenetic mechanisms, such as DNA methylation, have been implicated in the altered expression of Kv1.3 (39). The targeting of Kv1.3 selectively reduces tumor progression in mouse models of pancreatic ductal adenocarcinoma (40-42). Clofazimine promotes neoplastic B-cell death by inhibiting Kv1.3 in chronic lymphocytic leukemia (43). Kv1.1 blockers, such as KAaH1 and $\mathrm{KAaH} 2$, inhibit cell migration and adhesion in colon adenocarcinoma, breast cancer and glioblastoma (44). The tricyclic antidepressant imipramine, an antidepressant Kv10.1 antagonist, increases survival rates in patients with moderate Kv10.1 expression in brain cancers (45). The expression of Kv11.1 has been detected in pancreatic ductal adenocarcinoma (46) Furthermore, Kv11.1 has been demonstrated to participate in the P13K/Akt-dependent pathway, and its blockade inhibits tumor growth, angiogenesis, and metastasis (47).

Previous studies have analyzed the roles of $\mathrm{Kv}$ in various types of stem cells. For example, Wang et al (48) have reported that rat mesenchymal stem cells (MSCs) heterogeneously express distinct types of the $\mathrm{K}^{+}$channel, and that $\mathrm{Kv}$ channel activity modulates the cell cycle progression, affecting the proliferation of MSCs. Zhang et al (49) have reported that Kv10.1 regulates cell proliferation and differentiation in human bone marrow-derived MSCs. Morokuma et al (50) have demonstrated that the modulation of Kv7.1 confers a hyperproliferative invasive phenotype on embryonic stem cells. Bai et al (51) have described the various types of Kv expressed in human adipose tissue-derived stem cells. However, further studies are needed to clarify the expression, specific roles and functions of $\mathrm{Kv}$ in CSCs. To the best of our knowledge, the present study is the first to investigate the expression of $\mathrm{Kv}$ in PCSCs and the inhibitory effects of 4-AP, a potent $\mathrm{Kv}$ inhibitor, on their proliferation.

4-AP has been used as a medical agent to regulate the symptoms of MS $(52,53)$ and has demonstrated effectiveness as a symptomatic treatment for decreased walking capacity in patients with MS (52). Phase III trials reported an $25 \%$ increase in walking speed in $40 \%$ of patients and improved muscle strength in the lower extremities $(54,55)$, and 4-AP was approved as a compound by the U.S. Food \& Drug Administration in 2010. Furthermore, 4-AP exhibits antitumor activities against various types of cancer cells, such as neuroblastoma (56), Schwann cells cultured from tumors that arise in neurofibromatosis type 1 (57), melanoma (58), prostate cancer (59), malignant astrocytoma (60), hepatoblastoma (61), acute myeloid leukemia and glioma $(62,63)$ cells. Ru et al $(64)$ have reported that 4-AP induces glioma cell apoptosis by reducing the expression of microRNA-10b-5p. These anticancer activities of 4-AP are mostly attributed to its inhibition of Kv. However, the effects of 4-AP on CSCs remain unknown. The present study elucidated the mechanisms by which 4-AP may suppress the proliferation of CSCs through its effects as an inhibitor of Kv.

Luo et al (65) have recently demonstrated that 4-AP inhibits cell proliferation, induces apoptosis and enhances the sensitivity of a cisplatin (CDDP)-resistant lung cancer cell line to CDDP by upregulating phosphatase and tensin homolog, suggesting the potential of 4-AP as a therapeutic agent for patients with resistance to anticancer agents. Although advances have been achieved in chemotherapy for patients with pancreatic cancer through the application of various key agents, such as 5-FU, S-1, CDDP and gemcitabine, the prognosis of this cancer remains poor as recurrence is common in patients with advanced 
disease (1-7). In the present study, 4-AP inhibited tumorsphere formation in PCSCs and tumor growth in vivo compared with those in the corresponding control groups. Furthermore, 4-AP decreased the population of cells strongly expressing ALDH1A1 among PK59 cells. These results suggested the potential of 4-AP as a candidate drug in combination with anticancer agents for treatment-resistant pancreatic cancer.

Our previous studies demonstrated that $\left[\mathrm{Cl}^{-}\right]_{\mathrm{i}}$ controlled by $\mathrm{Cl}^{-}$channels may be an important messenger (28-31), and that a change in $\left[\mathrm{Cl}^{-}\right]_{\mathrm{i}}$ induced cell cycle arrest at the $\mathrm{G}_{0} / \mathrm{G}_{1}$ phase via mitogen-activated protein kinases in cancer cells $(28,29)$. Since $\mathrm{Cl}^{-}$is the counter ion of $\mathrm{K}^{+}$, the inhibition of $\mathrm{K}^{+}$channels may affect its movement (24). In the present study, the depletion of KCNB1 or treatment with 4-AP altered the fluorescence intensity of MQAE. These results suggested that $\mathrm{Kv}$ may regulate the stemness and cell proliferation by controlling $\left[\mathrm{Cl}^{-}\right]_{\mathrm{i}}$ in pancreatic cancer.

Pancreatic cancer is a desmoplastic tumor with fibroblasts, and a number of factors render the tumor environment a hostile milieu for antitumor immune cells, such as hypoxia, hypoglycemia and lactic acidosis (3-7). Therefore, a xenograft model does not simulate a real tumor. On the other hand, analysis of the cBioPortal database in the present study revealed that the expression levels of ALDH1A1 and KCNB1 positively correlated in primary tumor samples of human pancreatic cancer, suggesting that similar results to our in vitro analyses are obtainable under in vivo conditions.

In conclusion, the results of the present study demonstrated that several ion channels, including $\mathrm{Kv}$, were strongly expressed in PCSCs. The cytotoxicity of 4-AP against Kv was greater at a lower level in CSCs compared with that in non-CSCs. Although further studies are needed on the role and function of $\mathrm{Kv}$ in CSCs, its inhibitor 4-AP has potential as a novel therapeutic target against pancreatic cancer.

\section{Acknowledgements}

This study was supported by Grants-in-Aid for Scientific Research (C) (grant nos. 17K10602, 17K10710, 18K08628, 18K08689, 19K09202 and 19K09182) and a Grant-in-Aid for Young Scientists from the Japan Society for the Promotion of Science (grant no. 19K18160).

\section{Funding}

This study was supported by Grants-in-Aid for Scientific Research (grant nos. 17K10602, 17K10710, 18K08628, 18K08689, 19K09202 and 19K09182) and a Grant-in-Aid for Young Scientists (grant no. 19K18160) from the Japan Society for the Promotion of Science.

\section{Availability of data and materials}

The datasets used and/or analyzed during the current study are available from the corresponding author on reasonable request.

\section{Authors' contributions}

AS, TomK, TosK, MK, KK, HirI, KS, TA, HK, RM, SK, HisI, AT, TK, HF, KO and EO designed the research. AS, TomK and EO wrote the paper. AS, TomK, TosK, MK, KK and HirI performed cell culture, molecular biology and animal experiments. AS, TomK, KK and HirI confirm the authenticity of all the raw data. All authors have read and approved the final manuscript.

\section{Ethics approval and consent to participate}

All experimental methods were performed in accordance with relevant guidelines and regulations. The animal protocol was approved by the Institutional Animal Care and Use Committee of Kyoto Prefectural University of Medicine (Kyoto, Japan), and all experiments were performed in accordance with the National Institutes of Health Guide for Care and Use of Laboratory Animals.

\section{Patient consent for publication}

Not applicable.

\section{Competing interests}

The authors declare that they have no competing interests.

\section{References}

1. Siegel RL, Miller KD and Jemal A: Cancer statistics, 2017. CA Cancer J Clin 67: 7-30, 2017.

2. Ferlay J, Steliarova-Foucher E, Lortet-Tieulent J, Rosso S, Coebergh JW, Comber H, Forman D and Bray F: Cancer incidence and mortality patterns in Europe: Estimates for 40 countries in 2012. Eur J Cancer 49: 1374-1403, 2013.

3. Ilic M and Ilic I: Epidemiology of pancreatic cancer. World J Gastroenterol 22: 9694-9705, 2016.

4. Ishiwata T, Matsuda Y, Yoshimura H, Sasaki N, Ishiwata S, Ishikawa N, Takubo K, Arai T and Aida J: Pancreatic cancer stem cells: Features and detection methods. Pathol Oncol Res 2: 797-805, 2018.

5. Moore MJ, Goldstein D, Hamm J, Figer A, Hecht JR, Gallinger S, Au HJ, Murawa P, Walde D, Wolff RA, et al: Erlotinib plus gemcitabine compared with gemcitabine alone in patients with advanced pancreatic cancer: A phase III trial of the national cancer institute of Canada clinical trials group. J Clin Oncol 25: 1960-1966, 2007.

6. Louvet C, Labianca R, Hammel P, Lledo G, Zampino MG, André T, Zaniboni A, Ducreux M, Aitini E, Taïeb J, et al: Gemcitabine in combination with oxaliplatin compared with gemcitabine alone in locally advanced or metastatic pancreatic cancer: Results of a GERCOR and GISCAD phase III trial. J Clin Oncol 23: 3509-3516, 2005.

7. Hu G, Li F, Ouyang K, Xie F, Tang X, Wang K, Han S, Jiang Z, Zhu M, Wen D, et al: Intrinsic gemcitabine resistance in a novel pancreatic cancer cell line is associated with cancer stem cell-like phenotype. Int J Oncol 40: 798-806, 2012.

8. Clarke MF, Dick JE, Dirks PB, Eaves CJ, Jamieson CH, Jones DL, Visvader J, Weissman IL and Wahl GM: Cancer stem cells-perspectives on current status and future directions: AACR Workshop on cancer stem cells. Cancer Res 66: 9339-9344, 2006.

9. Visvader JE and Lindeman GJ: Cancer stem cells in solid tumours: Accumulating evidence and unresolved questions. Nat Rev Cancer 8: 755-768, 2008.

10. Toh TB, Lim JJ and Chow EK: Epigenetics in cancer stem cells. Mol Cancer 16: 29, 2017.

11. Long A, Giroux V, Whelan KA, Hamilton KE, Tetreault MP, Tanaka K, Lee JS, Klein-Szanto AJ, Nakagawa H and Rustgi AK: WNT10A promotes an invasive and self-renewing phenotype in esophageal squamous cell carcinoma. Carcinogenesis 36: 598-606, 2015.

12. Chen Q, Song S, Wei S, Liu B, Honjo S, Scott A, Jin J, Ma L, Zhu H, Skinner HD, et al: ABT-263 induces apoptosis and synergizes with chemotherapy by targeting stemness pathways in esophageal cancer. Oncotarget 6: 25883-25896, 2015. 
13. Yue D, Zhang Z, Li J, Chen X, Ping Y, Liu S, Shi X, Li L, Wang L, Huang L, et al: Transforming growth factor-betal promotes the migration and invasion of sphere-forming stem-like cell subpopulations in esophageal cancer. Exp Cell Res 336: 141-149, 2015.

14. Brungs D, Aghmesheh M, Vine KL, Becker TM, Carolan MG and Ranson M: Gastric cancer stem cells: Evidence, potential markers, and clinical implications. J Gastroenterol 51: 313-326, 2016.

15. Li Y, Rogoff HA, Keates S, Gao Y, Murikipudi S, Mikule K, Leggett D, Li W, Pardee AB and Li CJ: Suppression of cancer relapse and metastasis by inhibiting cancer stemness. Proc Natl Acad Sci USA 112: 1839-1844, 2015.

16. Shiozaki A, Ichikawa D, Otsuji E and Marunaka Y: Cellular physiological approach for treatment of gastric cancer. World J Gastroenterol 20: 11560-11566, 2014.

17. Shiozaki A, Ariyoshi Y, Iitaka D, Kosuga T, Shimizu H, Kudou M, Konishi T, Shoda K, Arita T, Konishi H, et al: Functional analysis and clinical significance of sodium iodide symporter expression in gastric cancer. Gastric Cancer 22: 473-485, 2019.

18. Kosuga T, Shiozaki A, Kudou M, Yamazato Y, Ichikawa D, Komatsu S, Konishi H, Okamoto K, Shoda K, Arita T, et al: Blockade of potassium ion transports enhances hypotonicity-induced cytocidal effects in gastric cancer. Oncotarget 8 : 101394-101405, 2017.

19. Kudou M, Shiozaki A, Yamazato Y, Katsurahara K, Kosuga T, Shoda K, Arita T, Konishi H, Komatsu S, Kubota T, et al: The expression and role of TRPV2 in esophageal squamous cell carcinoma. Sci Rep 9: 16055, 2019.

20. Shiozaki A, Kudou M, Ichikawa D, Fujiwara H, Shimizu H, Ishimoto T, Arita T, Kosuga T, Konishi H, Komatsu S, et al: Esophageal cancer stem cells are suppressed by tranilast, a TRPV2 channel inhibitor. J Gastroenterol 53: 197-207, 2018.

21. Darakhshan S and Pour AB: Tranilast: A review of its therapeutic applications. Pharmacol Res 91: 15-28, 2015.

22. Almanaa TN, Geusz ME and Jamasbi RJ: A new method for identifying stem-like cells in esophageal cancer cell lines. J Cancer 4: 536-548, 2013.

23. Johnson $S$, Chen $H$ and Lo PK: In vitro tumorsphere formation assays. Bio Protoc 3: e325, 2013.

24. Miyazaki H, Shiozaki A, Niisato N and Marunaka $Y$ Physiological significance of hypotonicity-induced regulatory volume decrease: Reduction in intracellular Cl- concentration acting as an intracellular signaling. Am J Physiol Renal Physiol 292: F1411-F1417, 2007.

25. Fan P, Zhang Y, Liu L, Zhao Z, Yin Y, Xiao X, Bauer N, Gladkich J, Mattern J, Gao C, et al: Continuous exposure of pancreatic cancer cells to dietary bioactive agents does not induce drug resistance unlike chemotherapy. Cell Death Dis 7: e2246, 2016.

26. Rasheed ZA and Matsui W: Biological and clinical relevance of stem cells in pancreatic adenocarcinoma. J Gastroenterol Hepatol 27 (Suppl 2): S15-S18, 2012.

27. Matsuda Y, Kure S and Ishiwata T: Nestin and other putative cancer stem cell markers in pancreatic cancer. Med Mol Morphol 45: 59-65, 2012.

28. Miyazaki H, Shiozaki A, Niisato N, Ohsawa R, Itoi H, Ueda Y, Otsuji E, Yamagishi H, Iwasaki Y, Nakano T, et al: Chloride ions control the G1/S cell-cycle checkpoint by regulating the expression of p21 through a p53-independent pathway in human gastric cancer cells. Biochem Biophys Res Commun 366: 506-512, 2008.

29. Ohsawa R, Miyazaki H, Niisato N, Shiozaki A, Iwasaki Y Otsuji E and Marunaka Y: Intracellular chloride regulates cell proliferation through the activation of stress-activated protein kinases in MKN28 human gastric cancer cells. J Cell Physiol 223 764-770, 2010.

30. Shiozaki A, Otsuji E and Marunaka Y: Intracellular chloride regulates the $\mathrm{G}(1) / \mathrm{S}$ cell cycle progression in gastric cancer cells. World J Gastrointest Oncol 3: 119-122, 2011.

31. Tanaka S, Miyazaki H, Shiozaki A, Ichikawa D, Otsuji E and Marunaka Y: Cytosolic Cl- affects the anticancer activity of paclitaxel in the gastric cancer cell line, MKN28 cell. Cell Physiol Biochem 42: 68-80, 2017.

32. Rausch V, Liu L, Kallifatidis G, Baumann B, Mattern J, Gladkich J, Wirth T, Schemmer P, Büchler MW, Zöller M, et al: Synergistic activity of sorafenib and sulforaphane abolishes pancreatic cancer stem cell characteristics. Cancer Res 70: 5004-5013, 2010.

33. Kim MP, Fleming JB, Wang H, Abbruzzese JL, Choi W, Kopetz S, McConkey DJ, Evans DB and Gallick GE: ALDH activity selectively defines an enhanced tumor-initiating cell population relative to $\mathrm{CD} 133$ expression in human pancreatic adenocarcinoma. PLoS One 6: e20636, 2011.
34. Rasheed ZA, Yang J, Wang Q, Kowalski J, Freed I, Murter C, Hong SM, Koorstra JB, Rajeshkumar NV, He X, et al: Prognostic significance of tumorigenic cells with mesenchymal features in pancreatic adenocarcinoma. J Natl Cancer Ins 102: 340-351, 2010.

35. Wu HY, Yang MC, Ding LY, Chen CS and Chu PC: p21-Activated kinase 3 promotes cancer stem cell phenotypes through activating the Akt-GSK3 $\beta$ - $\beta$-catenin signaling pathway in pancreatic cancer cells. Cancer Lett 456: 13-22, 2019.

36. Comes N, Serrano-Albarrás A, Capera J, Serrano-Novillo C, Condom E, Ramón Y, Cajal S, Ferreres JC and Felipe A: Involvement of potassium channels in the progression of cancer to a more malignant phenotype. Biochim Biophys Acta 1848: 2477-2492, 2015

37. Rao VR, Perez-Neut M, Kaja S and Gentile S: Voltage-gated ion channels in cancer cell proliferation. Cancers (Basel) 7: 849-875, 2015.

38. Serrano-Novillo C, Capera J, Colomer-Molera M, Condom E, Ferreres JC and Felipe A: Implication of voltage-gated potassium channels in neoplastic cell proliferation. Cancers (Basel) 11: 287, 2019.

39. Brevet M, Fucks D, Chatelain D, Regimbeau JM, Delcenserie R, Sevestre $\mathrm{H}$ and Ouadid-Ahidouch H: Deregulation of 2 potassium channels in pancreas adenocarcinomas: Implication of KV1.3 gene promoter methylation. Pancreas 38: 649-654, 2009.

40. Leanza L, Zoratti M, Gulbins E and Szabo I: Mitochondrial ion channels as oncological targets. Oncogene 33: 5569-5581, 2014.

41. Zaccagnino A, Managò A, Leanza L, Gontarewitz A, Linder B, Azzolini M, Biasutto L, Zoratti M, Peruzzo R, Legler K, et al: Tumor-reducing effect of the clinically used drug clofazimine in a SCID mouse model of pancreatic ductal adenocarcinoma. Oncotarget 8: 38276-38293, 2017.

42. Leanza L, Romio M, Becker KA, Azzolini M, Trentin L, Managò A, Venturini E, Zaccagnino A, Mattarei A, Carraretto L, et al: Direct pharmacological targeting of a mitochondrial ion channel selectively kills tumor cells in vivo. Cancer Cell 31: 516-531.e10, 2017.

43. Szabo I, Trentin L, Trimarco V, Semenzato G and Leanza L: Biophysical characterization and expression analysis of Kv1.3 potassium channel in primary human leukemic B cells. Cell Physiol Biochem 37: 965-978, 2015.

44. Aissaoui D, Mlayah-Bellalouna S, Jebali J, Abdelkafi-Koubaa Z, Souid S, Moslah W, Othman H, Luis J, ElAyeb M, Marrakchi N, et al: Functional role of Kv1.1 and Kv1.3 channels in the neoplastic progression steps of three cancer cell lines, elucidated by scorpion peptides. Int J Biol Macromol 111: 1146-1155, 2018

45. Martinez R, Stühmer W, Martin S, Schell J, Reichmann A, Rohde V and Pardo L: Analysis of the expression of Kv10.1 potassium channel in patients with brain metastases and glioblastoma multiforme: Impact on survival. BMC Cancer 15: 839, 2015.

46. Sette A, Spadavecchia J, Landoulsi J, Casale S, Haye B, Crociani $\mathrm{O}$ and Arcangeli A: Development of novel anti-Kv 11.1 antibody-conjugated $\mathrm{PEG}-\mathrm{TiO}_{2}$ nanoparticles for targeting pancreatic ductal adenocarcinoma cells. J Nanopart Res 15: 2111, 2013.

47. Crociani O, Lastraioli E, Boni L, Pillozzi S, Romoli MR, D'Amico M, Stefanini M, Crescioli S, Masi A, Taddei A, et al: hERG1 channels regulate VEGF-A secretion in human gastric cancer: Clinicopathological correlations and therapeutical implications. Clin Cancer Res 20: 1502-1512, 2014.

48. Wang SP, Wang JA, Luo RH, Cui WY and Wang H: Potassium channel currents in rat mesenchymal stem cells and their possible roles in cell proliferation. Clin Exp Pharmacol Physiol 35: 1077-1084, 2008

49. Zhang YY, Yue J, Che H, Sun HY, Tse HF and Li GR: BKCa and hEag1 channels regulate cell proliferation and differentiation in human bone marrow-derived mesenchymal stem cells. J Cell Physiol 229: 202-212, 2014.

50. Morokuma J, Blackiston D, Adams DS, Seebohm G, Trimmer B and Levin M: Modulation of potassium channel function confers a hyperproliferative invasive phenotype on embryonic stem cells. Proc Natl Acad Sci USA 105: 16608-16613, 2008.

51. Bai X, Ma J, Pan Z, Song YH, Freyberg S, Yan Y, Vykoukal D and Alt E: Electrophysiological properties of human adipose tissue-derived stem cells. Am J Physiol Cell Physiol 293: C1539-C1550, 2007.

52. Jensen HB, Ravnborg M, Dalgas $U$ and Stenager E: 4-Aminopyridine for symptomatic treatment of multiple sclerosis: A systematic review. Ther Adv Neurol Disord 7: 97-113, 2014. 
53. Solari A, Uitdehaag B, Giuliani G, Pucci E and Taus C: Aminopyridines for symptomatic treatment in multiple sclerosis. Cochrane Database Syst Rev 2002: CD001330, 2002.

54. Goodman AD, Brown TR, Edwards KR, Krupp LB, Schapiro RT, Cohen R, Marinucci LN and Blight AR; MSF204 Investigators: A phase 3 trial of extended release oral dalfampridine in multiple sclerosis. Ann Neurol 68: 494-502, 2010.

55. Goodman AD, Brown TR, Krupp LB, Schapiro RT, Schwid SR, Cohen R, Marinucci LN and Blight AR; Fampridine MS-F203 Investigators: Sustained-release oral fampridine in multiple sclerosis: A randomised, double-blind, controlled trial. Lancet 373: 732-738, 2009.

56. Rouzaire-Dubois B, Gerard V and Dubois JM: Involvement of $\mathrm{K}+$ channels in the quercetin-induced inhibition of neuroblastoma cell growth. Pflugers Arch 423: 202-205, 1993.

57. Fieber LA, González DM, Wallace MR and Muir D: Delayed rectifier K currents in NF1 Schwann cells. Pharmacological block inhibits proliferation. Neurobiol Dis 13: 136-146, 2003.

58. Nilius B and Wohlrab W: Potassium channels and regulation of proliferation of human melanoma cells. J Physiol 445: 537-548, 1992.

59. Rybalchenko V, Prevarskaya N, Van Coppenolle F, Legrand G, Lemonnier L, Le Bourhis X and Skryma R: Verapamil inhibits proliferation of LNCaP human prostate cancer cells influencing K+ channel gating. Mol Pharmacol 59: 1376-1387, 2001.
60. Chin LS, Park CC, Zitnay KM, Sinha M, DiPatri AJ Jr, Perillán P and Simard JM: 4-Aminopyridine causes apoptosis and blocks an outward rectifier $\mathrm{K}+$ channel in malignant astrocytoma cell lines. J Neurosci Res 48: 122-127, 1997.

61. Kim JA, Kang YS, Jung MW, Kang GH, Lee SH and Lee YS: $\mathrm{Ca} 2^{+}$influx mediates apoptosis induced by 4 -aminopyridine, a $\mathrm{K}+$ channel blocker, in HepG2 human hepatoblastoma cells. Pharmacology 60: 74-81,2000.

62. Wang W, Xiao J, Adachi M, Liu Z and Zhou J: 4-aminopyridine induces apoptosis of human acute myeloid leukemia cells via increasing $\left[\mathrm{Ca}^{+}\right] \mathrm{i}$ through $\mathrm{P} 2 \mathrm{X} 7$ receptor pathway. Cell Physiol Biochem 28: 199-208, 2011.

63. Huang L, Li B, Li W, Guo H and Zou F: ATP-sensitive potassium channels control glioma cells proliferation by regulating ERK activity. Carcinogenesis 30: 737-744, 2009.

64. Ru Q, Li WL, Xiong Q, Chen L, Tian X and Li CY: Voltage-gated potassium channel blocker 4-aminopyridine induces glioma cell apoptosis by reducing expression of microRNA-10b-5p. Mol Biol Cell 29: 1125-1136, 2018.

65. Luo Z, Wang J, Li C, Qiu Y, Huang J, Huang Y, Gu H, Wu B, Hu Z and Zhen Y: Upregulation of phosphatase and tensin homolog is essential for the effect of 4-aminopyridine on A549/CDDP cells. Mol Med Rep 17: 5996-6001, 2018.

This work is licensed under a Creative Commons Attribution-NonCommercial-NoDerivatives 4.0 International (CC BY-NC-ND 4.0) License. 